\title{
Research Published in Management International Review from 2006 to 2020: A Bibliometric Analysis and Future Directions
}

\author{
Debmalya Mukherjee $^{1} \cdot$ Satish Kumar ${ }^{2,3} \cdot$ Naveen Donthu $^{4} \cdot$ Nitesh Pandey $^{2}$
}

Received: 12 August 2021 / Revised: 29 August 2021 / Accepted: 30 August 2021 /

Published online: 13 October 2021

(C) The Author(s), under exclusive licence to Springer-Verlag GmbH Germany, part of Springer Nature 2021

\begin{abstract}
The Management International Review (MIR) celebrated its 60th anniversary in 2020. In commemoration of this event, we use a bibliometric analysis to present a retrospective on the journal by analyzing its content for the years between 2006 and 2020. We find that the collaboration culture in $M I R$ has risen over time with the increase in the median size of author teams. Moreover, the collaboration network has become more global over time. The methodology used in the journal is predominantly empirical and quantitative with archival data sources most commonly used. The bibliographic coupling of the MIR corpus reveals that the major themes in the journal revolve around "culture," "emerging economies," "innovation, knowledge transfer, and absorptive capacity," "internationalization process," "culture and entry modes," and "internationalization and performance." A comparison with other leading international business journals provides distinct pathways in which MIR may continue to grow. Finally, it is important to note that while the share of conceptual studies has decreased significantly in the last 15 years, the MIR editors want to see more novel and theoretically grounded conceptual articles in the journal.
\end{abstract}

Keywords International business · Bibliometric analysis · Co-authorship analysis · Bibliographic coupling $\cdot$ International management

\section{Introduction}

Founded in 1960, Management International Review (MIR) is one of the leading journals in the field of international management (IM). MIR publishes cutting edge research focusing on the topics related to IM, cross-cultural management, comparative management, and related international business (IB) issues. Thus, for more than

Debmalya Mukherjee

dmukher@uakron.edu

Extended author information available on the last page of the article 
60 years, MIR has served as a platform for rigorous intellectual conversations in the aforementioned domains. The journal publishes six issues per year, one of which, on average, is a focused or special issue. For its prolonged and high-level contributions to the field, MIR has been recognized by several peer-reviewed and citation-based metrics.

According to Scopus, the journal has a CiteScore of 4.5, indicating that the publications between 2017 and 2020 received an average of $4.5^{1}$ citations, and the source normalized impact per paper (SNIP) is 1.535 , indicating that the MIR publications have received, on average, 1.535 times more citations than the average citations in their subject areas. The Social Science Citation Index (SSCI) impact factor of MIR, as of 2020 , is $3.721,{ }^{2}$ indicating that its publications in 2018 and 2019 received on average 3.721 citations in 2020 alone. The 5-year impact factor is 5.062, meaning that the publications between 2016 and 2020 received 5.062 citations, on average, in 2020. The peer-review-based rankings also position MIR highly, with Australian Business Deans Council (ABDC) ranking the journal as ' $\mathrm{A}$ '3 and Chartered Association of Business Schools (CABS) ${ }^{4}$ rating the journal as ' 3 ' in its Academic Journal Guide (AJG) 2021 list.

MIR's success can be attributed to its status as one of the first journals in the field of IM and IB and the most diverse in terms of its author base (Oesterle \& Wolf, 2011). The journal was founded in Germany with Louis Perridon as its first editor in chief. He held the position until 1980, when Klaus Macharzina took over and remained at the helm until 2006. The current coeditors in chief, Michael Jörg Oesterle and Joachim Wolf, started in 2006. Under these editorial regimes, MIR has become one of the leading journals by becoming widely known outside the continental Europe and, in 2008, was listed on Social Science Citation Index by Clarivate Analytics.

In this paper, we attempt to take a stock of MIR's journey during 2006-2020. To this end, we use bibliometric analysis (Donthu et al., 2021a) to capture the evolution of MIR's intellectual structure, uncover emerging methodological and theoretical trends, better understand the nuances of $M I R$ 's impact on the field, and throw light on the journal's competitive positioning when compared to similar scientific outlets in its domain. Our attempt to present this $M I R$ retrospective is pertinent and timely given the commemoration of its $60^{\text {th }}$ anniversary. Indeed, it is not uncommon to publish studies such as this one on a journal's milestone year (Schwert, 1993), and many renowned journals, such as Journal of Business Research (Donthu et al., 2020), Journal of International Marketing (Donthu et al., 2021c), Journal of International Business Studies (García-Lillo et al., 2019), International Business Review (Rialp et al., 2019), and International Marketing Review (Donthu et al., 2021d),

\footnotetext{
1 The data regarding journal's Cite Score, Source Normalized Impact per Paper can be found at https:// www.scopus.com/sourceid/24392.

2 The data regarding journal's impact factor and 5-year impact factor https://www.springer.com/journal/ 11575 .

3 The ABDC rankings can be found at https://abdc.edu.au/research/abdc-journal-quality-list/.

4 AJG ratings can be found at https://charteredabs.org/academic-journal-guide-2021/.
} 
have benefited from similar endeavors. To present a comprehensive retrospective, we ask several key questions framed as research questions (RQs).

First, we examine the collaboration and methodological choices of MIR's authors. Collaboration patterns enable understanding in the development of any field, as the contributing authors often form distinct groups across the institutional and intellectual lines, and studying such patterns help us to make sense of the underlying ties and emerging connections in a given field. Second, we explore authors' methodological choices because knowledge and practice of dominant methodologies are important for a scholar's success in academia (Hanson \& Grimmer, 2007). Third, we evaluate the major themes in MIR corpus and identify the emerging ones, which helps us in paving the path for future scholars. Fourth, we investigate the drivers of MIR citations because citations, which indicate the impact of scientific publications, are a primary measure of a journal's quality (Mingers \& Yang, 2017). Finally, we present a comparison of $M I R$ with other leading journals in the field of IM and IB, which is useful in identifying growth opportunities for MIR in the coming decades. The RQs are answered using a range of tools, such as coauthorship analysis, bibliographic coupling, network examination, and regression analysis. The RQs are framed as follows.

Research Question 1: What are the different collaboration patterns of MIR authors?

Research Question 2: What methodologies do MIR authors use in their research?

Research Question 3: What are the major themes explored by MIR authors?

Research Question 4: What factors drive MIR citations?

Research Question 5: How does MIR compare to other leading journals in the field?

The rest of the study is organized as follows. Section 2 provides an overview of bibliometric analysis as it pertains to the fields of IM and IB. Section 3 presents the overview of the study's bibliometric methodology and analytical strategy. Section 4 presents the analysis of collaboration and methodological choices of MIR authors. Section 5 presents the analysis of major themes, and Sect. 6 presents the analysis of citations drivers. Section 7 compares MIR with other leading IB journals in terms of rankings and themes. Finally, Sect. 8 concludes the study.

\section{The IB/IM Field and Bibliometric Analysis}

IB as a field emerged in the 1950s with research being almost exclusively done by scholars from United States (Oesterle \& Wolf, 2011). The research output of IB has steadily grown over the years; the field now has multiple and thriving subdomains. This is in stark contrast with the early 1970s, when it was argued that the entire IB research area could be summarized in a single volume (Wright \& Ricks, 1994). However, the past two decades have witnessed tremendous growth in IB activities and related research outputs. Thus, the use of advanced techniques, such as bibliometric analysis, has become more common and frequent in IB research (Calma \& Suder, 2020; Zhao et al., 2018). The extant bibliometric analyses point toward two important issues. First, IB research has increasingly become more variegated in terms of subdomains, themes, theories, methodologies, and author's country of 
origin. Second, the corpus size in each of these areas is large enough to justify the application of bibliometric analysis (Donthu et al., 2021a).

Studies employing bibliometric techniques focusing on a single journal are becoming common. For instance, Rialp et al. (2019) examine International Business Review's development in terms of citation and publication while also presenting major themes using the analysis of author keywords. Donthu et al., (2021c, 2021d) throw light on the international marketing (a subfield of IB) by focusing on Journal of International Marketing and International Marketing Review, respectively. The major takeaway from the abovementioned studies is that the use of bibliometrics in the IB field is becoming prevalent.

\section{Methodology}

In simple terms, bibliometric analysis is the application of quantitative techniques on bibliographic data (Donthu et al., 2021a). The main advantage of the technique is its ability to handle large amounts of bibliographic data (Ramos-Rodrígue \& RuízNavarro, 2004).

To identify the collaboration patterns, we conduct a coauthorship analysis of $M I R$, which includes study on the author team sizes in each period. In addition, we conduct a network analysis of the MIR country-level collaboration patterns to show how collaborative ties have developed in $M I R$.

To shed light on the methodological choices of MIR authors, we classified each article based on its methodology. The choice of methodology has been identified as one of the drivers of citations in previous research (Dang \& Li, 2020; Stremersch et al., 2007; Valtakoski, 2019). Two of the authors independently read the full articles, coded them, and classified each article by its industrial focus, regional focus, research methods (i.e., empirical, conceptual, literature review, and modelling and analytical) ${ }^{5}$ research design (i.e., qualitative, quantitative, or mixed), data collection (i.e., case study, interview, archival, survey, or experiment), and data analytics method. ${ }^{6}$

To identify major themes in MIR's corpus, we use bibliographic coupling. Bibliographic coupling assumes that the publications sharing literature references share common themes as well (Kessler, 1963), with a greater number of shared literature references indicating a higher degree of thematic similarity (Wallin, 2005). We use

\footnotetext{
5 The data collection techniques are defined as literature review (i.e., if the article is a review of the discipline, research topic(s), or methodology), empirical (i.e., if it contained any form of "real" data), modelling and analytical (i.e., if the article is based only on mathematical derivations and/or simulated/ created datasets), conceptual (i.e., if the article does not include any data and is primarily based on logic and discussion of theoretical frameworks), and mixed (i.e., if articles have any combination of these methods). Above classification is based on Gupta et al. (2006).

6 The data analysis methodologies are defined as descriptive (e.g., total, means, and any others results that involved only basic statistical tests: T-test and chi-square), correlations, regression (e.g., OLS, probit, logit, logistics, multinomial, ordered logit, double hurdle Heckman 2LS, 3 SLS, etc.), and others (e.g., mathematical model, SEM, EFA, CFA, ANOVA, ANCOVA, MANOVA, MANCOVA, etc.). Listed classification is based on Gupta et al. (2006).
} 
shared literature references to construct document clusters by using a variant of the algorithm by Newman and Girvan (2004). Here, each major cluster represents a major theme in the journal. The clusters were ordered based on the number of documents in them. We conduct cluster analyses of each major cluster to understand their major themes.

To analyze the drivers of $M I R$ citations, we use negative binomial regression. As the chosen measure of article impact (i.e., the citation count) is a count variable with zero values and is over-dispersed, the negative binomial regression is a preferred method of analysis (Stremersch et al., 2007; Valtakoski, 2019). This is in line with the previous literature (Baker et al., 2020; Donthu et al., 2021b; Stremersch et al., 2007; Valtakoski, 2019) that has looked into identifying the major article attributes that drive future citations.

The search was conducted in May 2021 using the source search by name 'Management International Review' on Scopus, resulting in 503 documents between the years 2006 and 2020. After further cleaning the data by removing duplicates, notes, and other erroneous entries, 491 documents remained that were used for further analysis. To compare MIR with other leading IB journals, we use the list provided by Tüselmann et al. (2016) with the cutoff of AJG rating of '3.' The journals short-listed this way were Journal of International Business Studies (JIBS), Journal of World Business (JWB), Global Strategy Journal (GSJ), International Business Review (IBR), Asia Pacific Journal of Management (APJM), Journal of International Management (JIM), and Management and Organization Review (MOR). We fetched the data for these journals from Scopus for the period 2006-2020. We then used the data as input for VOSviewer (van Eck \& Waltman, 2010) and Gephi (Bastian et al., 2009) for network visualization. Figure 1 represents the research design for this study.

\section{Collaboration and Methodological Choices Among MIR Authors}

The analysis of collaboration and methodological choices of MIR authors helps in understanding what research has taken place in $M I R$ over time. Figure 2 shows the consistent increase in the author team sizes (RQ1). It is evident in the figure that, between 2006 and 2010, the publications with two authors held the share of publications for the journal at $41.32 \%$, followed by articles with three authors at $29.94 \%$. It is also evident that, at least since 2006 , the journal has a strong collaboration culture with a share of single-authored articles remaining small throughout. However, the increase in collaboration culture may not be limited just to MIR as the increasing complexity of themes and the availability of newer methodological techniques have led to greater collaboration in the broader field of organizational research as well (Acedo et al., 2006). Between 2011 and 2015, the share of articles with two authors has decreased to $39.39 \%$, while the articles with more than two authors has increased, with the share of three-author articles at $33.94 \%$ and four-author articles at $10.91 \%$. This trend continues in the period between 2016 and 2020, during which the highest share of articles is commanded by articles with three authors (40.25\%). The median author team size has shifted from two between 2006 and 2015 to three 


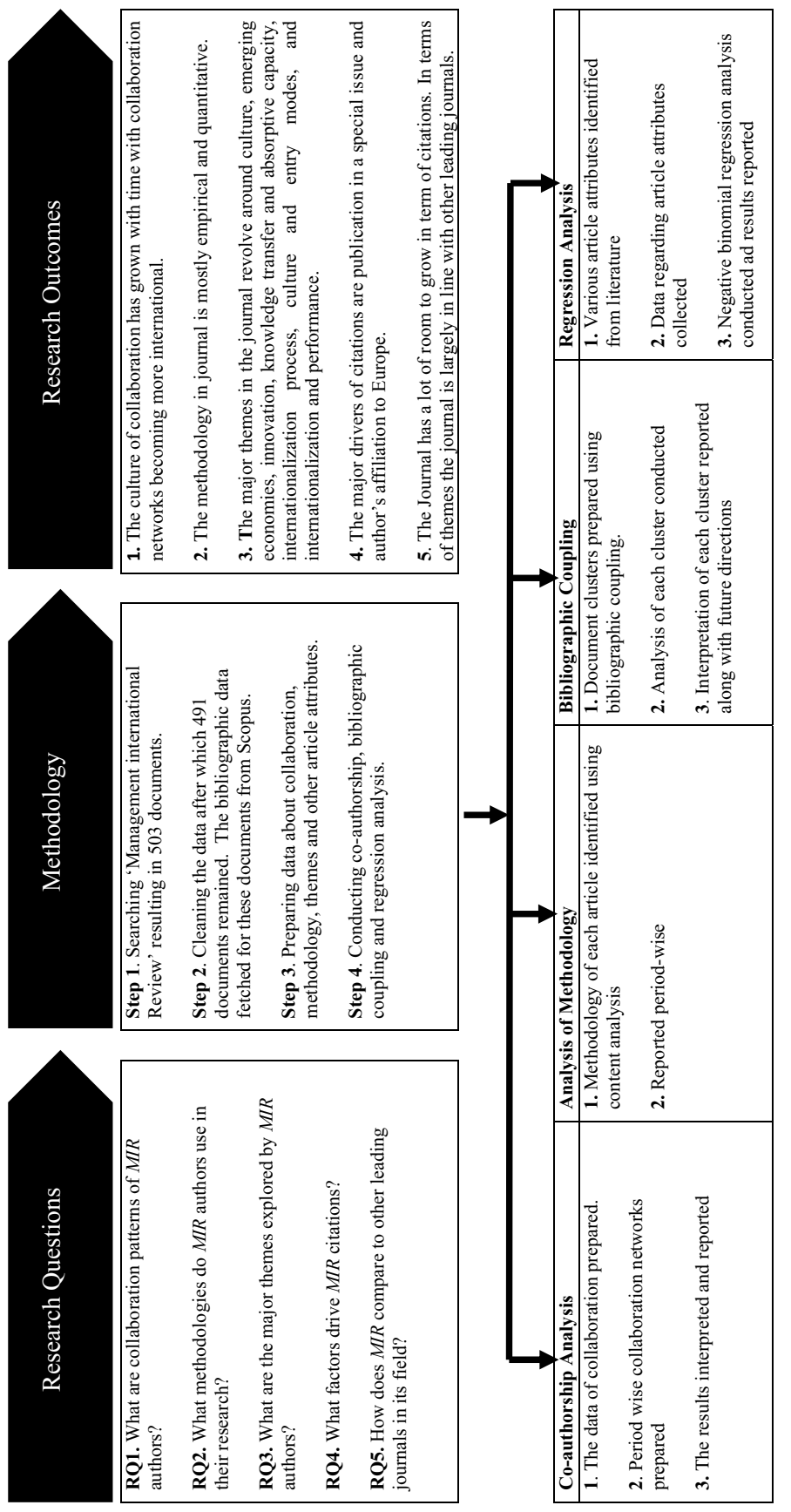

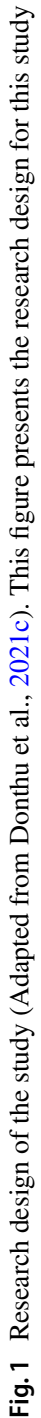




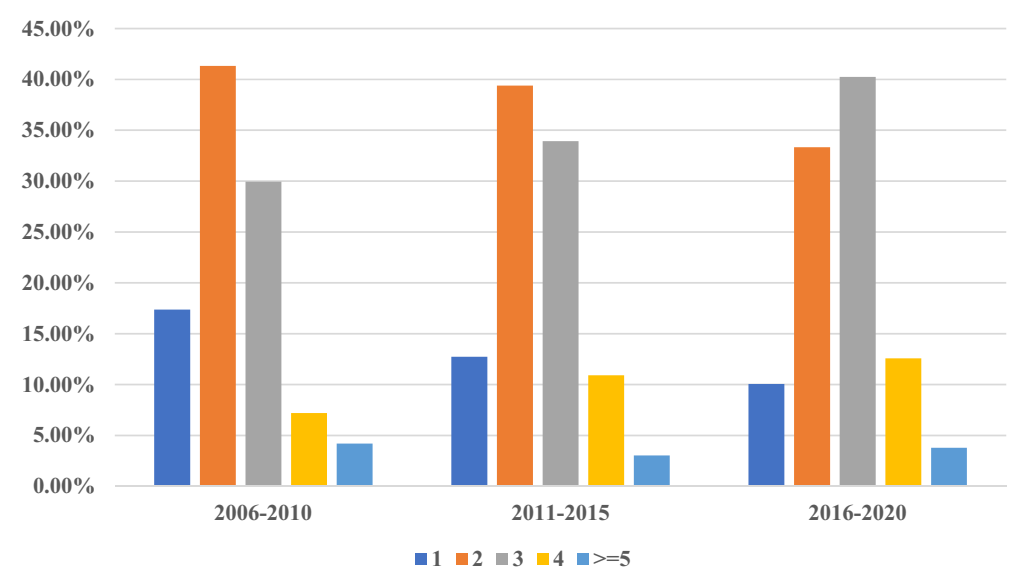

Fig. 2 Authors' collaboration patterns in MIR between 2006 and 2020. In this figure the x-axis represents the period, y-axis represents the number (\%age) of articles and the legends represents the number of authors

between 2016 and 2020. This may be driven by increased results of increasing complexities in research topics and methodology (Acedo et al., 2006). Furthermore, larger author teams garner more citations on account of the published article having greater social connectivity (Valtakoski, 2019). With increasing complexity in research and the benefits offered in terms of citations, the author team's median size is expected to grow further.

Figure 3 shows the collaboration patterns at the country-level between 2006 and 2010. Here, the bubble size represents the number of connections any particular country has with other countries in the network, and the link thickness represents the number of times those two countries appear together in author affiliations. Between 2006 and 2010, USA, UK, Canada, and Netherlands appear to be the most important components of the network, with United States and Canada showing a particularly strong link. Between 2011 and 2015 (Fig. 4), the role of United Kingdom has grown significantly, showing a particularly strong coauthorship bond with China. Similarly, the roles of Australia and China have grown significantly between the periods with UK, USA, Australia, China and Canada, making a strong network in which author teams from these countries were common during the chosen time period. Between 2016 and 2020 (Fig. 5), the network became more complex, with USA and UK being the most important components but also sharing a strong link with each other. The prominence of USA as an MIR author-base does not come as a surprise as the region has been a fertile ground for IB research since the inception of this field.

RQ2 sheds light on the methodological context and choices made by the MIR authors. Table 1 shows the industrial and regional emphasis of the research that has taken place in the journal. Panel A in Table 1 shows the industry focus of MIR research. In this table, the categories are listed in the alphabetic order, and notations depicting classification in multiple categories ('both') or lack of classification in any category ('no focus mentioned') are placed after other classifications 


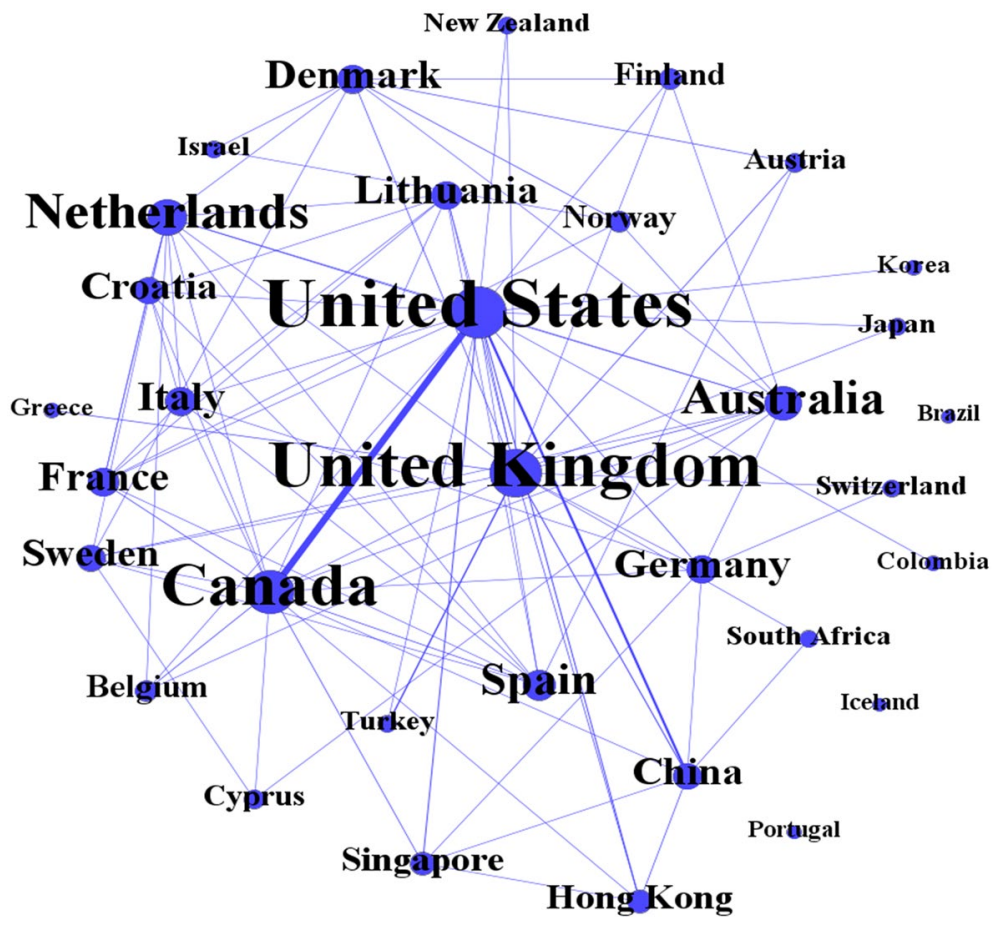

Fig. 3 Country collaboration network between 2006 and 2010. This figure presents the county level collaboration network for MIR between 2006 and 2010

in their respective panels. The research usually covers services and manufacturing sectors, but the attention has shifted toward services in the last 15 years for studies covering a single industry. For instance, research focusing on only the service industries increased to $15.72 \%$ between 2016 and 2020, from $8.33 \%$ between 2006 and 2010. At the same time, the share of articles focusing only on manufacturing industries has decreased from 20.83 to $18.87 \%$. This is consistent with the increase in the importance of services in the world economy during the past two decades (Blagoeva et al., 2020; Merchant \& Gaur, 2008). The country choices presented in Panel B shows that the research published in the journal usually focuses on a single country. Among the single-country articles, the focus has been put more on Asia, which has an overall research share of $54.10 \%$. Though the majority of articles have focused on Asia, plenty of focus has been on Europe and North America, with the share of articles at $27.27 \%$ and $13.06 \%$, respectively. A small but consistent attention has been on Australia, New Zealand, and South America. Studies on Africa has been almost nonexistent, with only a few articles published recently (e.g., Glaister et al., 2020). As firms from continental Africa continue to internationalize, it may be important for MIR to encourage further research to better understand African firms' idiosyncrasies and heterogeneous nuances. 


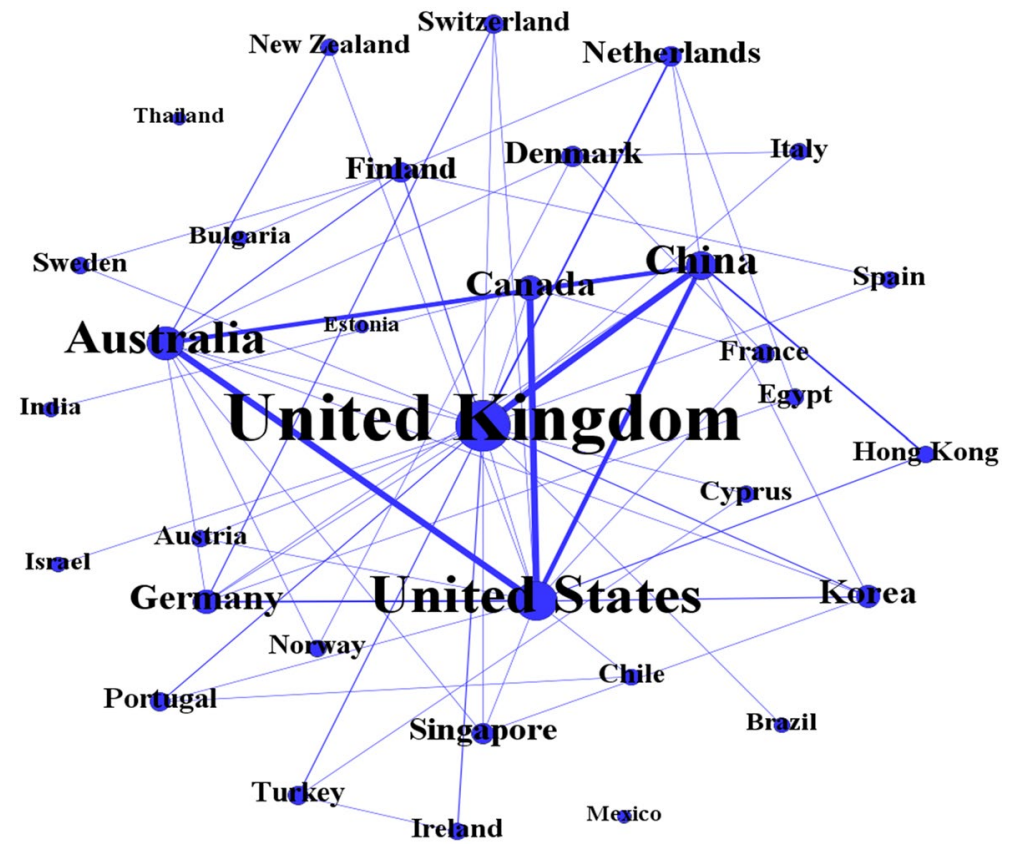

Fig. 4 Country collaboration network between 2011 and 2015. This figure presents the county level collaboration network for MIR between 2011 and 2015

Table 2 shows the pattern of methodological choices (RQ2). Panel A shows a research method pattern, and it is evident that the research that has taken place in the journal since 2006 has been empirical in nature. The share of conceptual studies has gone down from $19.64 \%$ between 2006 and 2010 to $8.18 \%$ between 2016 and 2020 . The share of literature reviews has grown from 4.17 to $10.06 \%$ in the same period. The research design pattern shows that the research in the journal has primarily used the quantitative design, with its share at $86.18 \%$. The share of qualitative research has shown a small decline from $11.31 \%$ between 2006 and 2010 to $10.06 \%$ between 2016 and 2020, while quantitative research design has gone from 86.31 to $88.68 \%$ in the same period. Panel $\mathrm{C}$ shows the data collection techniques. Here, the archival data has the dominant share at $60.77 \%$. However, the share has gone down from 64.29 to $59.12 \%$. On the other hand, the survey share has seen a rise from 27.98 to $32.08 \%$. Qualitative interviews have risen too, with case studies showing a small decline. Data collection though experimentation forms a miniscule research share. It can be concluded that, while the data collection techniques in the journal have been diverse, these are heavily skewed in favor of archival data. Panel D shows the pattern of data analysis techniques used in the journal. The categories do not appear to be mutually exclusive in the table, as a single study may use multiple types of data analysis techniques. Here, the descriptive data analysis (e.g., measures of central tendency, $t$ test, and $f$ test) is most common at $73.78 \%$, followed by correlation at $67.28 \%$ and regression at $55.28 \%$. It is to be noted that descriptive analyses are used almost always to complement the main empirical models. The other analysis 


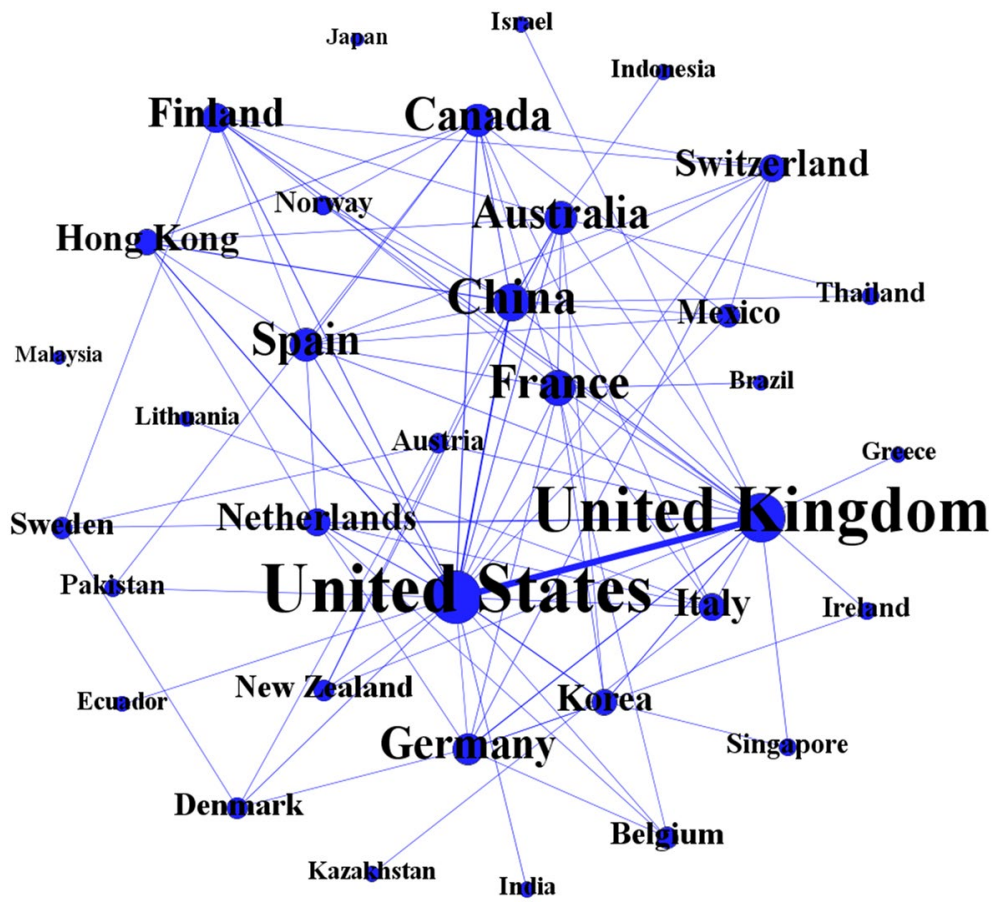

Fig. 5 Country collaboration network between 2016 and 2020. This figure presents the county level collaboration network for MIR between 2016 and 2020

Table 1 The industry and regional focus in MIR articles during 2006-2020

\begin{tabular}{lcccc}
\hline & $2006-2010(\%)$ & $2011-2015(\%)$ & $2016-2020(\%)$ & Total (\%) \\
\hline Panel A: Industry focus & & & & 10.77 \\
Service & 8.33 & 8.48 & 15.72 & 18.90 \\
Manufacturing & 20.83 & 16.97 & 18.87 & 49.39 \\
Both & 48.81 & 51.52 & 47.80 & 20.93 \\
No industry focus mentioned & 22.02 & 23.03 & 17.61 & 54.47 \\
Panel B: Single/Multi country focus & & & 27.03 \\
Single country & 54.76 & 50.91 & 57.86 & 18.50 \\
Multi country & 22.62 & 33.94 & 24.53 & 17.61 \\
No country focus mentioned & 22.62 & 15.15 & & 0.37 \\
Panel C: Regional focus of single country focus & & 1.09 & 54.10 \\
Africa & 0.00 & 0.00 & 56.52 & 2.99 \\
Asia & 48.91 & 57.14 & 2.17 & 27.24 \\
Australia and New Zealand & 4.35 & 2.38 & 31.52 & 13.06 \\
Europe & 26.09 & 23.81 & 6.52 & 2.24 \\
North America & 16.30 & 16.67 & 2.17 & \\
South America & 4.35 & 0.00 & & \\
\hline
\end{tabular}


Table 2 Methodological choices among MIR authors

\begin{tabular}{|c|c|c|c|c|}
\hline & 2006-2010(\%) & $2011-2015(\%)$ & 2016-2020(\%) & Total $(\%)$ \\
\hline \multicolumn{5}{|l|}{ Panel A: Research method } \\
\hline Empirical & 73.21 & 84.85 & 81.13 & 79.67 \\
\hline Conceptual & 19.64 & 6.67 & 8.18 & 11.59 \\
\hline LR survey and review & 4.17 & 8.48 & 10.06 & 7.52 \\
\hline Modelling and analytical & 2.98 & 0.00 & 0.63 & 1.22 \\
\hline \multicolumn{5}{|l|}{ Panel B: Research design } \\
\hline Qualitative & 11.31 & 14.55 & 10.06 & 11.99 \\
\hline Quantitative & 86.31 & 83.64 & 88.68 & 86.18 \\
\hline Mixed design & 2.38 & 1.82 & 1.26 & 1.42 \\
\hline \multicolumn{5}{|c|}{ Panel C: Data collection methods } \\
\hline Case study & 5.95 & 9.70 & 5.66 & 7.11 \\
\hline Qualitative interview & 7.14 & 8.48 & 11.95 & 9.15 \\
\hline Archival & 64.29 & 58.79 & 59.12 & 60.77 \\
\hline Survey & 27.98 & 32.12 & 32.08 & 30.69 \\
\hline Experiment & 0.60 & 0.00 & 1.89 & 0.81 \\
\hline No data reported/collected & 0.00 & 0.61 & 2.52 & 1.02 \\
\hline \multicolumn{5}{|c|}{ Panel D: Data analysis techniques } \\
\hline Descriptive & 70.24 & 75.76 & 75.47 & 73.78 \\
\hline Correlation & 62.50 & 70.91 & 68.55 & 67.28 \\
\hline Regression & 50.00 & 59.39 & 56.60 & 55.28 \\
\hline Others & 46.43 & 42.42 & 51.57 & 46.75 \\
\hline Not mentioned & 1.79 & 0.00 & 1.89 & 1.22 \\
\hline
\end{tabular}

Others include Structured equation modeling, confirmatory factor analysis (CFA), explanatory factor analysis (EFA), discriminant analysis, cluster analysis, simulation, and various variance-based techniques (ANOVA, MANOVA, MANCOVA etc.)

methods contain a range of techniques, such as ANOVA, MANOVA, MANCOVA, structural equation modelling (SEM), exploratory factor analysis (EFA), confirmatory factor analysis (CFA), and so forth. These techniques are varied in nature and indicate that the authors' use of data analysis techniques have been diverse.

\section{Major Themes in MIR Corpus}

To study the major themes within MIR corpus (RQ3), we used bibliographic coupling analysis. This technique works under the assumption that the shared literature references determine the thematic similarity between the articles. The application of bibliographic coupling on the MIR corpus led to the creation of nine document clusters. Among these, six are major clusters containing 488 of 491 documents $(99.39 \%$ of the total corpus). The remaining three clusters contain one article each. We conducted a content analysis of six major clusters. Among these, Cluster 1 contains 135 articles (27.49\% of the corpus) focusing on the topic of culture; Cluster 2 contains 
121 articles (24.64\%) focusing on emerging economies; Cluster 3 contains 84 articles $(17.11 \%)$ focusing on innovation, knowledge transfer, and absorptive capacity; Cluster 4 contains 64 articles (13.03\%) focusing on the internationalization process; Cluster 5 contains 46 articles $(9.37 \%)$ focusing on culture and entry modes; and Cluster 6 contains 38 articles $(7.74 \%)$ focusing on the topics related to internationalization and performance. Tables $3,4,5,6,7,8$ present summaries of each cluster.

\subsection{Cluster 1: Culture}

The themes of this cluster are related to culture. Table 3 presents the cluster summary. The focal point of the studies in this area seems to be the cross-cultural management issues, with particular attention on the cultural differences, expatriates, cultural values, trust, and psychic distance. Throughout the years, the MIR authors have explored the relationship between the IM strategies in national and sociocultural contexts. The most cited studies in this particular cluster focus on the topics related to language (Welch \& Welch, 2008) and qualitative and mixed research methods in the field of cross-cultural management and IM (Hurmerinta-Peltomäki \& Nummela, 2006; Sinkovics \& Alfoldi, 2012; Sinkovics et al., 2008; Welch \& Piekkari, 2006).

The period-wise cluster analysis shows that, between 2006 and 2010, the MIR authors explored the topic of culture with a focus on language (Table 3). The cultural contexts of China emerge as a prominent topic, along with home country brand image (Zeugner-Roth et al., 2008), role of managers in multinational enterprises (MNEs) (Vora et al., 2007), cross-border mergers and acquisitions (Søderberg, 2006), diversity in top management teams (Gong, 2006), human resource practices (Kwon et al., 2010), host country influence on top management teams (Bhardwaj et al., 2007), and cultural accommodation (Akkermans et al., 2010). In sum, the themes during this period focused primarily on a range of factors related to cultural context and its impact on organizational outcomes.

The themes of cultural context have been further developed in the next period (2011-2015), with MIR authors dealing with the topics of national culture, expatriates, cultural differences, indigenous management, and psychic distance. During this period, China remained a dominant research context. This is consistent with the rise of China as one of the leading economies and increased IB activities occurring in and out of the country. The authors explored these key themes through their impacts on corporate governance (Daniel et al., 2012), offshore outsourcing (Manning et al., 2011), gender and cultural stereotyping (Hutchings et al., 2013), global supply chains (Sinkovics et al., 2011), and other institutional factors relating to compliance with local laws, politics, and cultural values. The themes of cultural issues have been explored in the contexts of offshoring, global sourcing (Lin, 2020), and international expatriates. This suggests that, during this period (2016-2020), MIR authors explored topics related to outsourcing and IM issues. The authors have continued to develop an understanding of culture (Taras et al., 2016) and cultural values (Jintae et al., 2016). In addition to the cultural values, other key themes explored by MIR authors during this time include knowledge sharing (Sinkovics et al., 2019) and R\&D (Lee et al., 2020a, 2020b) in a cross-cultural context. The journal continued 


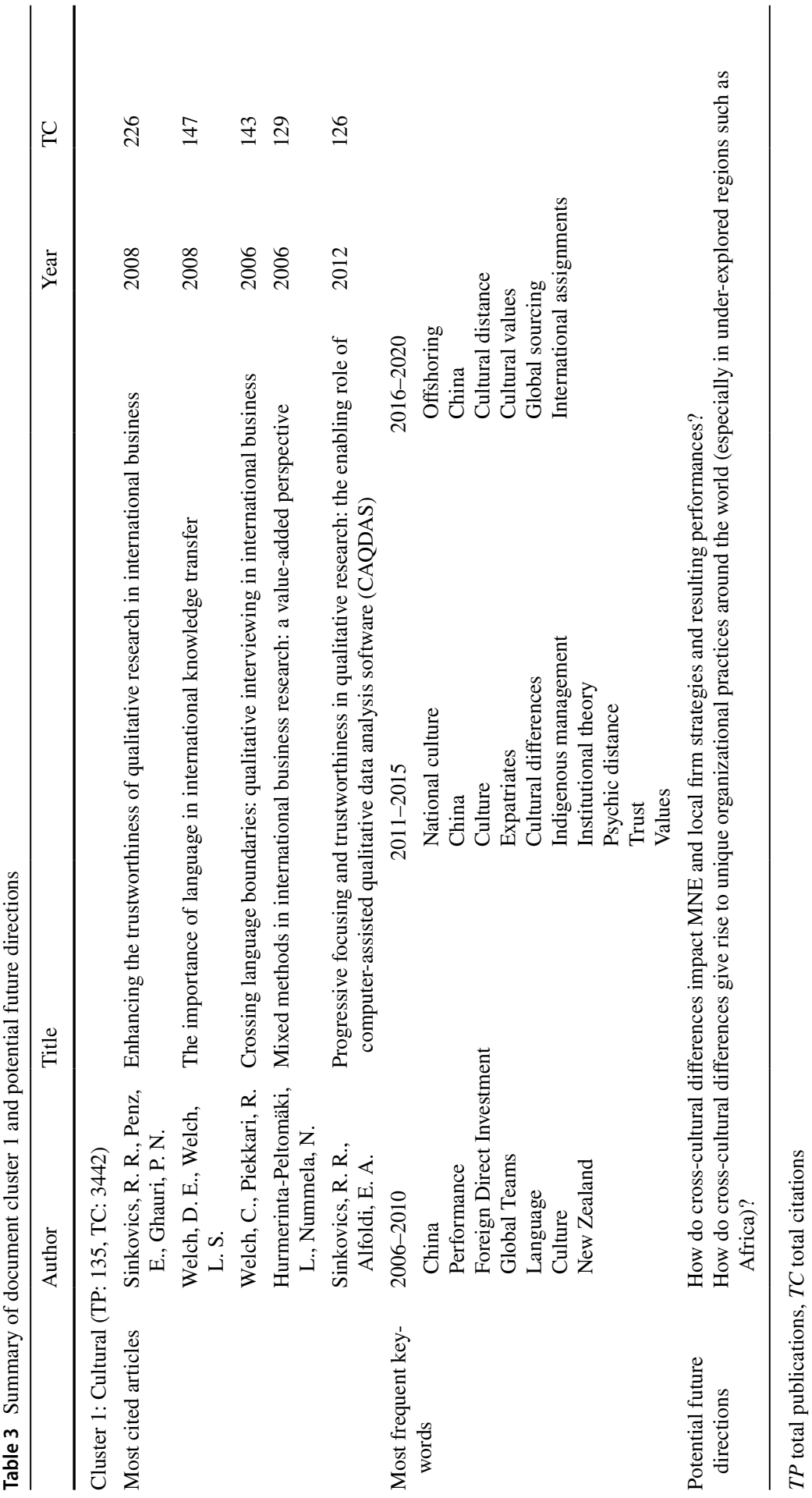




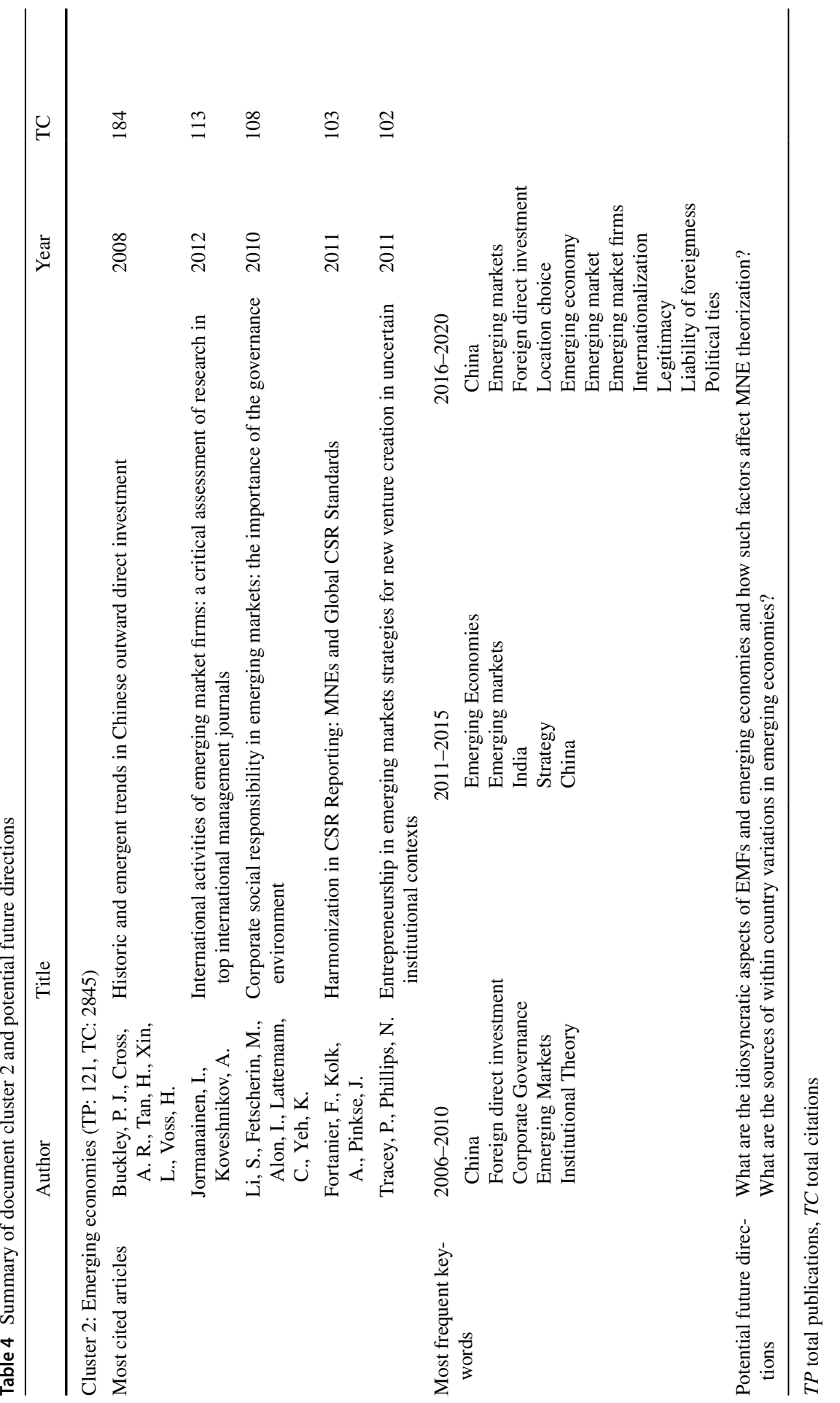




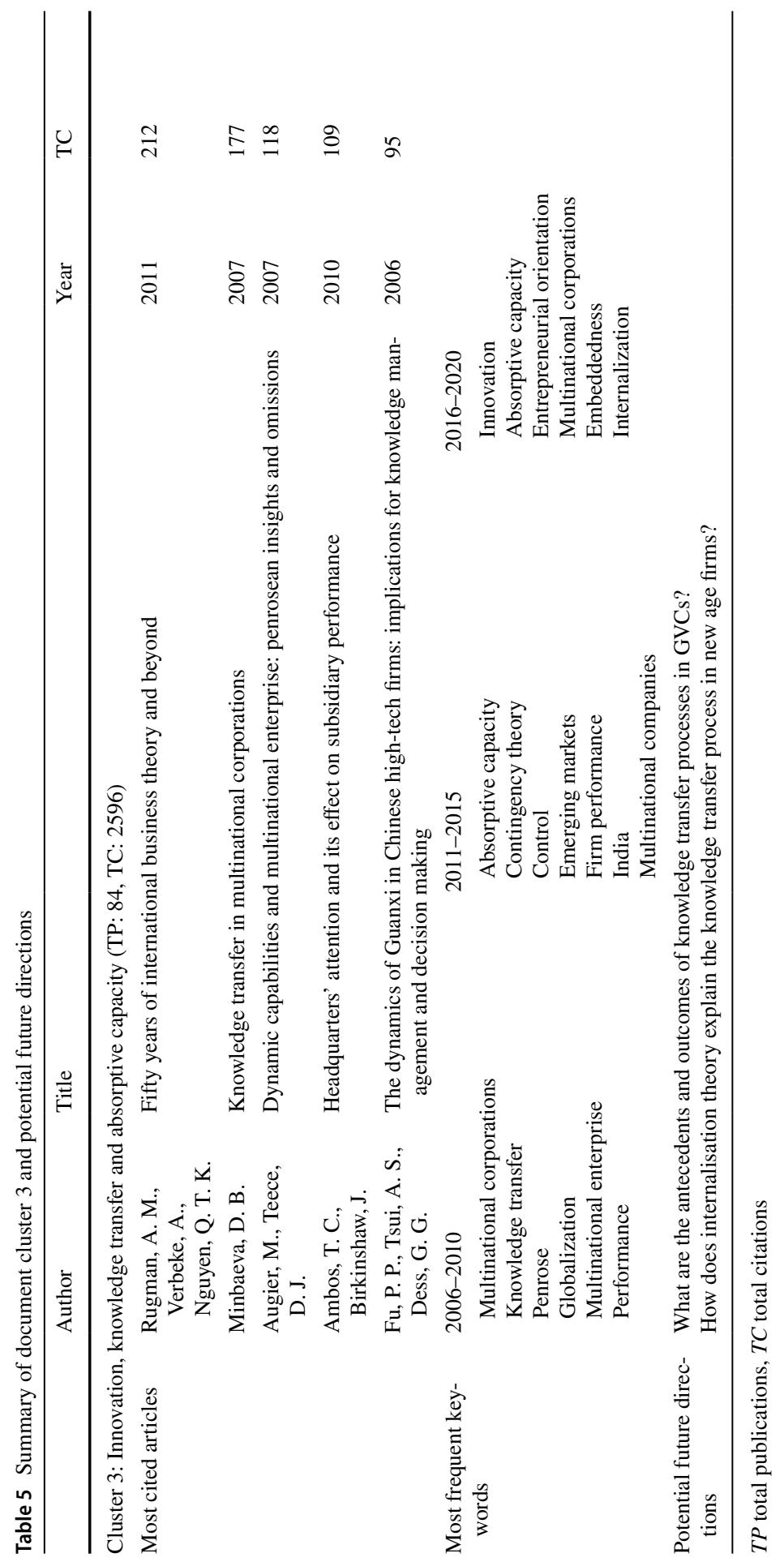




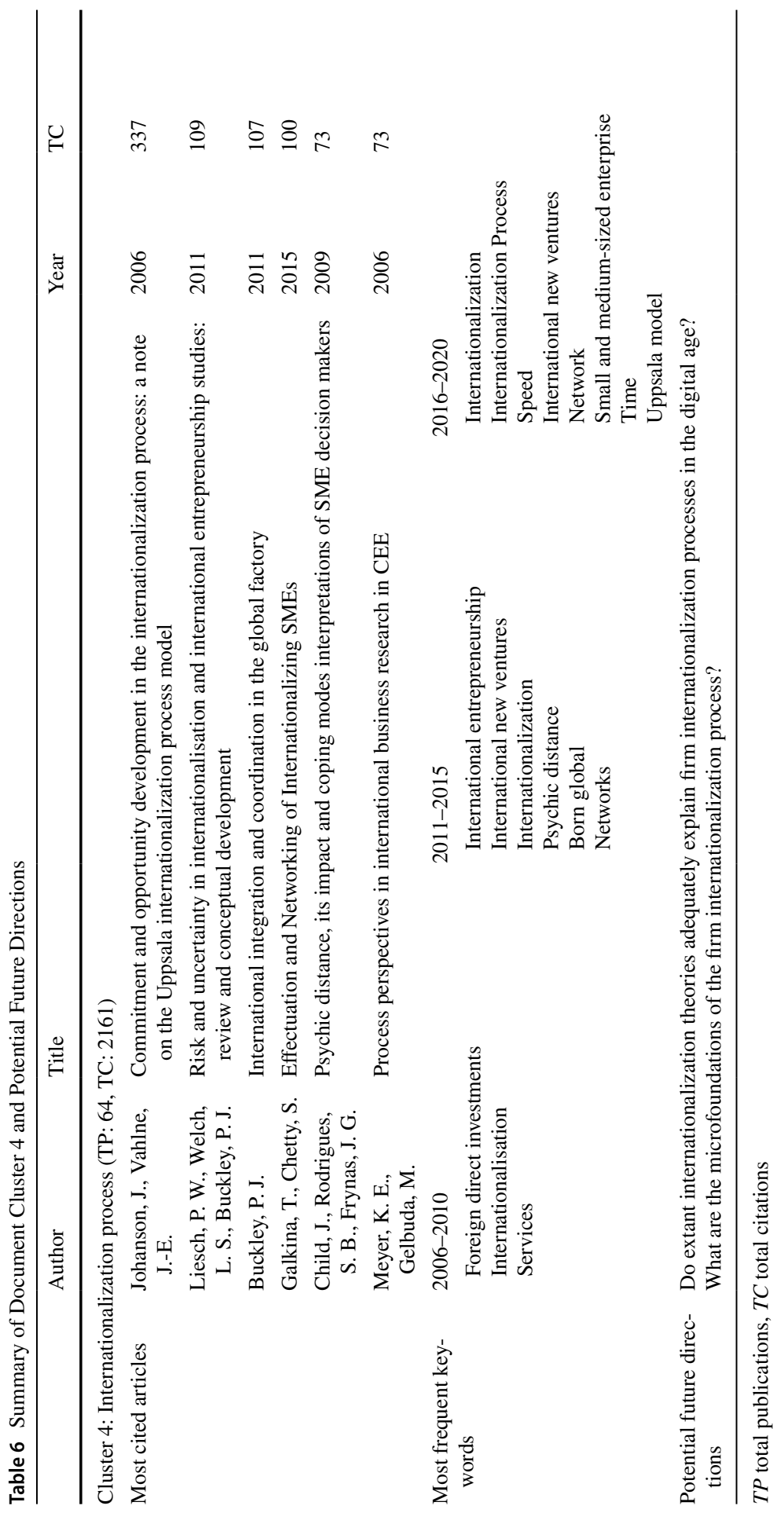




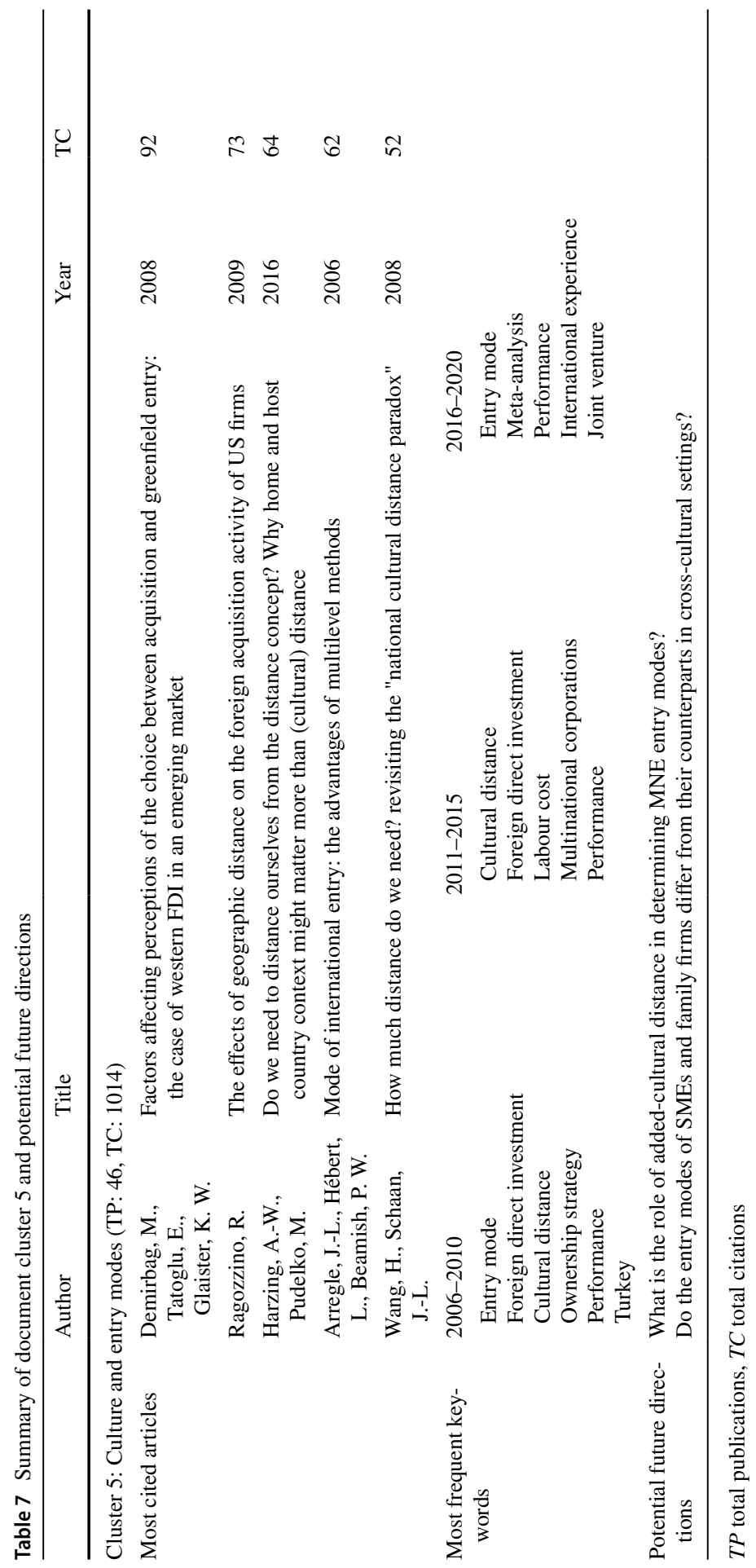




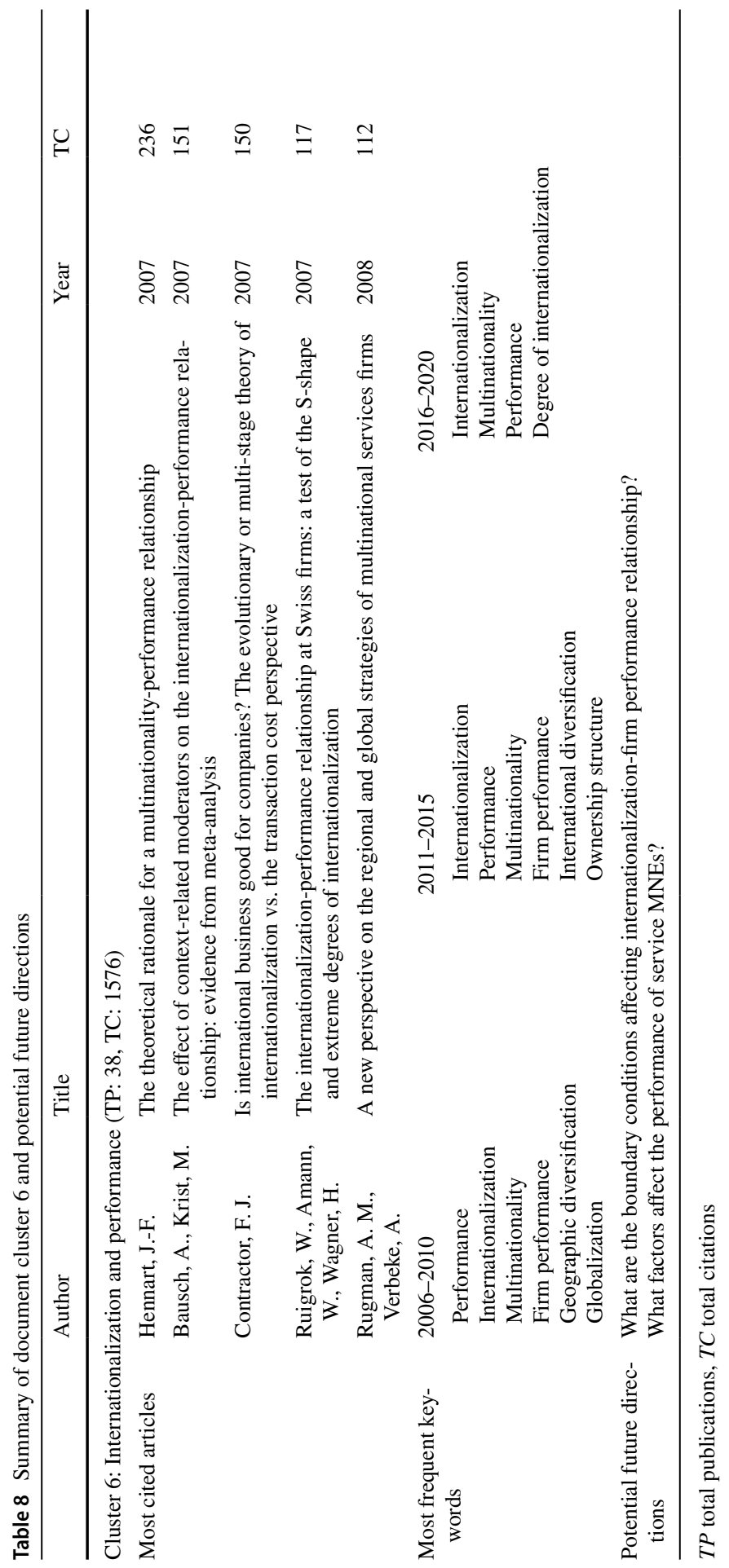


to explore the different themes on cross-cultural context, and more recent research points toward several topics that may be explored in the future. These include the expatriates, with attention on HRM in a cross-cultural context, the effect of cultural differences on knowledge connectivity and $R \& D$, and the process of offshore outsourcing with focus on the role of cultural differences.

While the Hofstede cultural dimensions (see Taras et al., 2016 for a meta-analytic review) and GLOBE study (Dorfman et al., 2012; House et al., 2004) have had most impact on the field, it will be important for IB scholars to explore other cultural dimensions further, such as Trompenaars (1993) and Triandis (1994), to obtain more nuanced understanding of different cultures and their impacts on IB activities. Moreover, while cross-cultural IB research has proliferated and has gone beyond the initial Anglo-Saxon focus, many regions, such as Latin America, Africa, and the Middle-East, remain under-researched and, thus, underrepresented in comparative IB studies. Relatedly, most cross-cultural IB studies rely on quantitative techniques. It is imperative for IB scholars to employ ethnography and other qualitative methodologies to obtain fine-grained, contextual information as to how cross-cultural variations may influence MNE and local firm behavior. Thus, we put forth the following two broad future research questions:

- How do cross-cultural differences impact MNE and local firm strategies and resulting performances?

- How do cross-cultural differences give rise to unique organizational practices around the world (especially in under-explored regions, such as Africa)?

\subsection{Cluster 2: Emerging Economies}

The studies in this cluster primarily deal with the topics related to the emerging economies, specifically focusing on the rapid internationalization of emerging market firms (EMFs) (Jormanainen \& Koveshnikov, 2012). Table 4 presents the cluster summary. The central themes, as expressed in the top keywords in each period, suggested that the authors focused on such topics as the corporate governance, strategy, and operations in the institutional environment of emerging economies and markets. Other factors influencing the strategy have been examined. These included the study of political ties and liability of foreignness issues of MNEs. Many keywords between this and cluster 1 were similar, but one must appreciate the fact that some topics, such as FDI and the institutional context of China, have been studies from different vantage points. For instance, while in cluster 1, such topics were studied with regards to culture, this cluster focuses more on the institutional context of emerging economies. This is in line with the rising prominence of the institutionbased view as one of the important paradigms in IB literature (Lahiri et al., 2020; Peng et al., 2008). As for the most-cited articles in this cluster, the focus was on topics such as corporate social responsibility in emerging markets (Fortanier et al., 2011; Li et al., 2010), internationalization and (Jormanainen \& Koveshnikov, 2012), outward FDI by EMFs (Buckley et al., 2008), and entrepreneurial strategies in an emerging market context (Tracey \& Phillips, 2011). 
The period-wise theme analysis suggested that the MIR authors between 2006 and 2010 focused more on the institutional context of emerging markets. These included the CSR issues in emerging markets and EMF internationalization. Other key topics included brand positioning and anti-counterfeit measures (Yang \& Fryxell, 2009), response of MNEs to the low-cost imports in their home countries (Kaufmann \& Körte, 2010), and trade disputes (Lindeque \& McGuire, 2007). The research conducted during this time focused on the perspective of emerging markets and emerging market MNEs (EMNEs), rather than the developed market firms doing business in and with them.

The major keywords between years 2011 and 2015 suggest that the focus of the MIR authors remained on the strategic choices of emerging markets in the institutional context, with a focus on emerging economies, such as India and China. The subject of entrepreneurship in emerging markets (Tracey \& Phillips, 2011) gained significance during this time, with topics such as knowledge sharing (Kedia et al., 2012), acquisitions (Rabbiosi et al., 2012), and other strategic choices made by EMFs.

The themes in this cluster were further developed during 2016 and 2020, with MIR authors focusing on topics such as location choices for plants (Jain et al., 2016). Authors also focused on topics related to political connections (Banerjee \& Venaik, 2018; Liedong \& Frynas, 2018), corruption (Jiménez et al., 2017), and political risk (Han et al., 2018). As IB research continues to examine contextual heterogeneity among emerging economies (Pattnaik et al., 2020; Scalera et al., 2020) and EMF internationalization issues (Kumar et al., 2020; Mukherjee et al., 2021; Nuruzzaman et al., 2020), future scholars may focus their attention on the following two broad directions:

- What are the idiosyncratic aspects of EMFs and emerging economies and how do such factors affect MNE theorization?

- What are the sources of cross and within-country variations in emerging economies?

\subsection{Cluster 3: Innovation, Knowledge Transfer, and Absorptive Capacity}

This cluster comprised 84 articles that had been cited 2596 times. Table 5 presents the cluster summary. The cluster's central theme revolved around the topic of MNE knowledge transfer and the related outcomes. The cluster's keywords indicated a focus on the topics related to the knowledge transfer, globalization, Penrosian theory on growth of firms, absorptive capacity, entrepreneurial orientation, and innovation. The keywords also suggested a focus on the institutional context of India. The cluster's most-cited articles focused on topics such as MNE knowledge management (Fu et al., 2006; Minbaeva, 2007), dynamic capabilities of MNEs (Augier \& Teece, 2007), subsidiary performance (Ambos \& Birkinshaw, 2010), and the state of IB research (Rugman et al., 2011).

The temporal analysis shows that, between 2006 and 2010, the cluster focused on topics related to knowledge transfer, with knowledge management as a key theme, 
and globalization. In addition, the firm's performance was explored through references to topics such as organizational learning ( $\mathrm{Mu}$ et al., 2007), the role of MNE headquarters (Ambos \& Mahnke, 2010), loss of competence due to outsourcing (Kotabe et al., 2008), and international R\&D (Criscuolo \& Narula, 2007).

These themes were further developed in the next period (2011-2015). The publication in the cluster seems to have decreased, with publications going from 42 between 2006 and 2010 to 27 between 2011 and 2015. The major themes explored during this time remained similar to the previous period, with authors continuing to focus on the topics related to organizational learning (Elango \& Pattnaik, 2011), overseas R\&D (D'Agostino \& Santangelo, 2012), knowledge transfer processes (Nair et al., 2015; Najafi-Tavani et al., 2012; Perez-Nordtvedt et al., 2015), procedural justice (Verbeke et al., 2013), and other topics related to the management of firms in foreign markets. These topics, much like in the previous period, were studied with reference to their effects on firm performance.

During the latest period (2016-2020), the publications in this cluster reduced further to 15. Similar to the previous periods, the focus remained on the knowledge transfer (Ferreras-Méndez et al., 2019; Lind et al., 2017), absorptive capacity (Zeng et al., 2019), and R\&D (Jha et al., 2018). Interestingly, the intellectual movement surrounding innovation and knowledge transfer shifted toward examining these concepts in the context of global value chains (GVCs), where a plethora of firms are interconnected and give rise to an ecosystem (Sinkovics et al., 2019; Soontornthum et al., 2020). This trend is also evident in the recent findings related to knowledge connectivity issues in GVCs and new age firms in other journals (Ambos et al., 2021; Mudambi et al., 2017). Thus, the aforementioned topics pave the way for future studies that may explore the following:

- What are the antecedents and outcomes of knowledge transfer processes in GVCs?

- How does internalization theory explain the knowledge transfer process in new age firms?

\subsection{Cluster 4: Firm Internationalization Process}

The cluster's central theme was the firm-internationalization process. Table 6 presents the cluster summary. The most frequent keywords appearing in this cluster's articles primarily focused on the internationalization process, with exploration of such topics as international entrepreneurship, born global phenomenon, and the role of networks in internationalization. The cluster's most-cited articles focused on topics related to the Uppsala internationalization process model (Johanson \& Vahlne, 2006), risk and uncertainty in international entrepreneurship (Liesch et al., 2011), global factories (Buckley, 2011), networking in internationalization of SMEs (Galkina \& Chetty, 2015), and the role of psychic distance in SME internationalization (Child et al., 2009).

As per the cluster's temporal analysis, the central focus of authors in this cluster between 2006 and 2010 was on the topics related to the internationalization process 
and service. The focal point of this cluster's $M I R$ authors focused on the internationalization process from the perspective of the Uppsala internationalization process model (Johanson \& Vahlne, 2006), psychic distance and its role in SME decisionmaking (Child et al., 2009), the relationship between social ties and entry modes in foreign markets (Zhao \& Hsu, 2007), and service internationalization (Ball et al., 2008).

The coverage of topics somewhat increased during the next period (2011-2015), with authors focusing more on international entrepreneurship. MIR authors under this cluster focused on topics related to the risk and uncertainty in internationalization and international entrepreneurship (Liesch et al., 2011), coordination and integration of global factories (Buckley, 2011), networking practices of SMEs during internationalization (Galkina \& Chetty, 2015), born global firms (Hagen \& Zucchella, 2014; Nummela et al., 2014), and role of international experience in choice of establishment modes (Dow \& Larimo, 2011). With the development of themes established during the previous period, the authors also focused on the topic of internationalization of new ventures and born global firms.

During the latest period (2016-2020), the MIR authors further developed the themes from the previous period. This is indicated by the focus on the relationship between internationalization speed and firm performance (Hilmersson \& Johanson, 2016; Mohr \& Batsakis, 2017) and, more recently, the learnings in SME internationalization (Lee et al., 2020a, 2020b) and the role of social identity in the internationalization of family firms (Mondal et al., 2021; Wei et al., 2020). Topics related to family firms (Arregle et al., 2021; Casprini et al., 2020; Xu et al., 2020), SME internationalization (Lahiri et al., 2020), and ownership issues (Scalera et al., 2020) also became predominant in other IB journals. As businesses rely more on digital technologies and are connected via digital platforms (Kim \& Cavusgil, 2020; Makarius et al., 2020), it will be important to examine the extant internationalization theories in light of this new reality. Similarly, researchers are examining the managerial level attributes that impact firm internationalization process (Contractor et al., 2019; Kumar et al., 2021; Vahlne \& Johanson, 2020). Thus, the potential future directions for this cluster could be as follows:

- Do extant internationalization theories adequately explain firm internationalization processes in the digital age?

- What are the microfoundations of the firm internationalization process?

\subsection{Cluster 5: Culture and Foreign Entry Modes}

The cluster's central theme was the foreign entry modes in relation to the culture. Table 7 presents the cluster summary. The most frequent keywords in the cluster suggested that the authors studied entry modes and their relationships with cultural distance. Along with this topic, joint ventures and ownership strategies have been discussed, as well as labor cost. The most-cited studies in this cluster focused on the factors driving the choice of entry (Demirbag et al., 2008), foreign market entry through acquisition (Ragozzino, 2009), multilevel methods of international entry 
(Arregle et al., 2006), and the concept of cultural distance (Harzing \& Pudelko, 2016; Wang \& Schaan, 2008).

The temporal analysis of this cluster revealed that, between 2006 and 2010, the cluster focused on themes related to entry modes, with focus on cultural distance and ownership strategies. The institutional context of Turkey gained prominence during this time. The choice of entry modes have been studied with special focus on acquisition (Demirbag et al., 2008; Ragozzino, 2009). In addition, international joint ventures gained attention (Burgers \& Padgett, 2009), as did foreign subsidiaries and their performances (Dhanaraj \& Beamish, 2009).

During the next time period (2011-2015), the themes were further developed. The keywords during this period suggested that the authors continued to focus on the concepts of cultural distance. In addition, authors explored the joint venture exit strategies (Nemeth \& Nippa, 2013), exit strategy during times of financial crisis (Chung et al., 2013), divestment of subsidiaries (Song, 2014), and institutional barriers to international acquisitions (Moschieri et al., 2014).

During the latest period (2016-2020), the most prominent themes in the cluster still revolved around the entry modes with attention to join ventures. Cultural distance remained a central concept during this time (Harzing \& Pudelko, 2016) along with exit strategies. At the same time, the concept of added cultural distance has become more prominent in the broader IB domain (Kim et al., 2020). Also, the more recent articles in this cluster pointed to the topic of control of FDI by family firms (Del Bosco \& Bettinelli, 2020) which is in line with the emerging trends in the IB field (Mariotti et al., 2021). These pointed toward the following research directions:

- What is the role of added-cultural distance in determining MNE entry modes?

- Do the entry modes of SMEs and family firms differ from their counterparts in cross-cultural settings?

\subsection{Cluster 6: Internationalization and Performance}

The cluster's central theme revolved around internationalization strategy and form performance. Though the subject has been studied in various other contexts, the focus here was on strategic decision-making regarding internationalization, specifically on topics of geographical diversification, multinationality, and degree of internationalization. The most-cited articles in this cluster focused on topics such as multinationality (Hennart, 2007), internationalization and form performance relationship (Bausch \& Krist, 2007; Ruigrok et al., 2007), transaction cost perspective (Contractor, 2007), and strategies of service MNEs (Rugman \& Verbeke, 2008). The cluster summary is presented in Table 8 .

The major keywords in each of the three periods suggested that the MIR authors focused on the topic of internationalization and performance at different times. Between 2006 and 2010, the articles generally focused on topics related to the firm's performance, its relationship to a firm's internationalization and multinationality, the country of origin (Elango \& Sethi, 2007), services outsourcing (Contractor \& Mudambi, 2008), corporate diversification (Singh et al., 2010), and technological 
competence (Tihanyi et al., 2009). These have been studied with regards to their impact on internationalization and performance relationship.

Between 2011 and 2015, the themes of the previous period were developed further. During these times, the authors focused on the international diversification (Gaur \& Delios, 2015; Majocchi \& Strange, 2012), family management (Tsao \& Lien, 2013), and global orientation (Cerrato \& Piva, 2015). The studied topics remained connected to the central theme of internationalization and performance.

Between 2016 and 2020, the topics were further developed with the addition of the board's co-working experience, the board's influence on the director's decisionmaking (Chen et al., 2017), home country political connection (Bai et al., 2019), and more recently, the degree of internationalization in service MNEs (Wei \& Nguyen, 2020). The more recent themes have the potential for further development, with authors focusing on topics that examine boundary conditions of the internationalization and performance relationship and factors affecting the performance of service MNEs. Accordingly, the two broad research directions are as follows:

- What are the boundary conditions affecting the internationalization-firm performance relationship?

- What factors affect the performance of service MNEs?

\section{Drivers of MIR Article Citations}

As a scholar's growth depends on publication in high-quality journals (Guffey \& Harp, 2014) and such quality rankings often depend on citations (Mingers \& Yang, 2017), exploration of the factors that drive citations of any journal is interesting. To determine the impact drivers of $M I R$ articles, we used negative binomial regression. The model is suitable for studies when the dependent variable is a count variable that includes zeroes and is over-dispersed (Stremersch et al., 2007; Valtakoski, 2019). We based the choice of independent variables on previous literature (Chan et al., 2009; Dang \& Li, 2020; Rosenzweig et al., 2016; Schwert, 1993; Stremersch et al., 2007; Valtakoski, 2019). We based our theoretical framework on that of Stremersch et al. (2007) and Meyer et al. (2018), drawing from theoretical perspectives of universalism, social constructivism, and presentation. Table 9 presents the variables in the model, as well as their definitions.

\subsection{Variable Definitions}

\subsubsection{Dependent Variable}

As a measure of article impact, this study considered the number of citations received by an article. Citations are a common measure of article impact (Meyer et al., 2018; Stremersch et al., 2007; Valtakoski, 2019). Citations are recognized as an objective measure of an article's impact (Hota et al., 2019). In the context of this study, citations served as a suitable measure of an article's impact. 


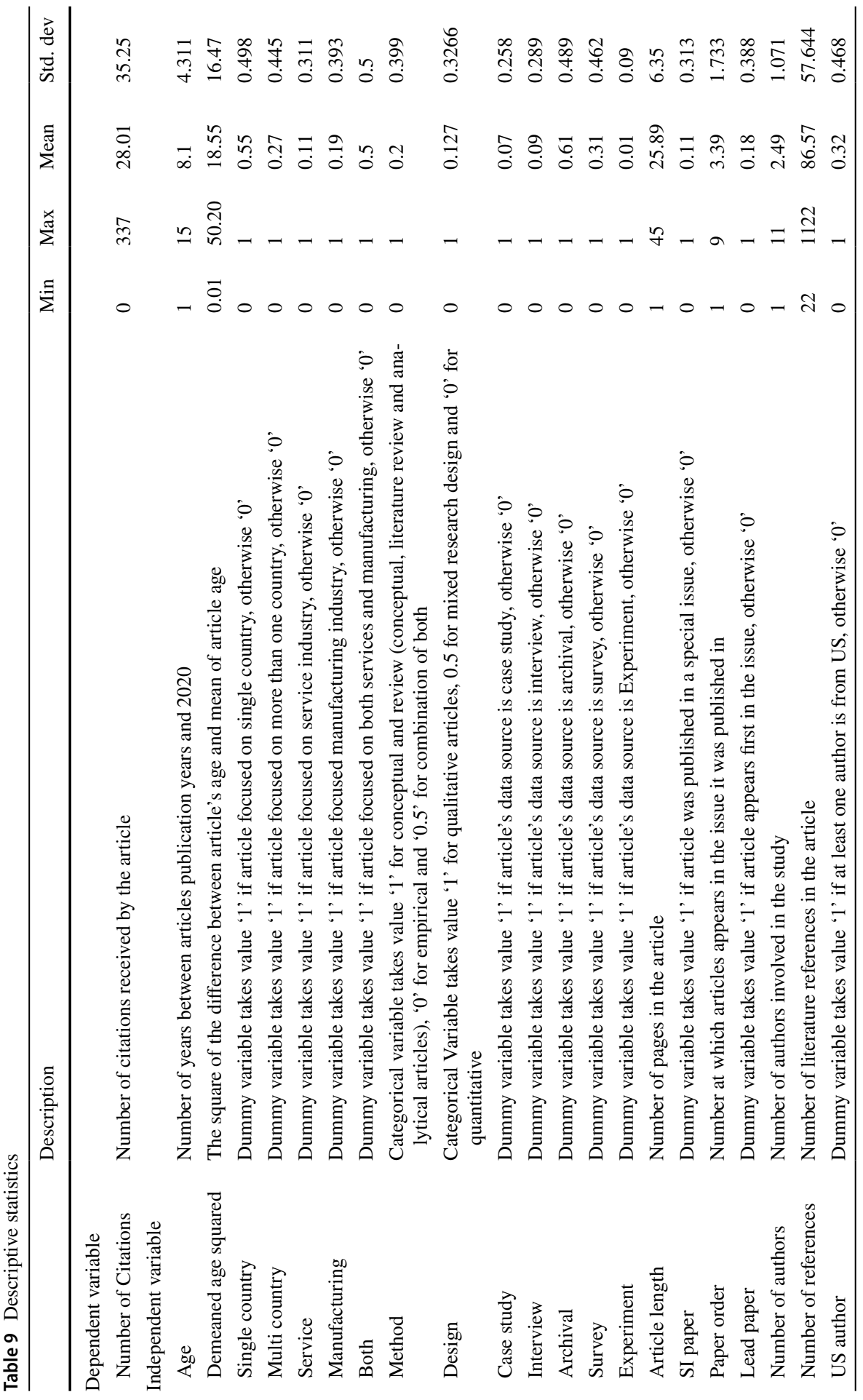




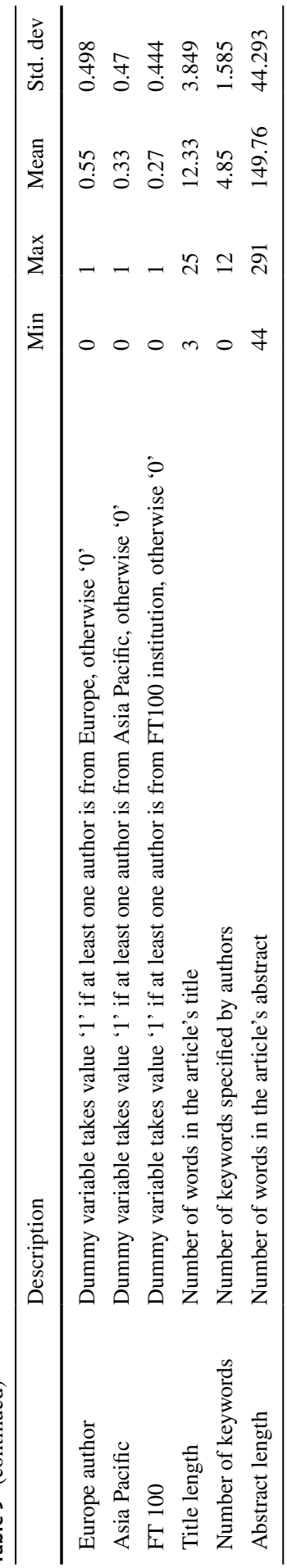




\subsubsection{Control Variables}

Researchers have consistently found "article age" to be a driver of citations in previous studies (e.g., Baker et al., 2020). Scholars have also noted that this article may not be linear (Stremersch et al., 2007). Therefore, we included the demeaned age squared variable, which is the square of the difference between an article's age and the average of all citations (Meyer et al., 2018).

\subsubsection{Independent Variables}

According to universalism, an article's impact is dependent upon its content (Meyer et al., 2018), including an article's domain (e.g., regional focus and methodology) and quality. Under this perspective, the variables such as regional focus of the study, methodological choices, are operationalized as method, design, and data sources (e.g., case studies, interviews, archives, surveys, and experiments). For other variables indicative of content, we take into account the article length (indicative of the content amount) and special issues (indicative of an article having novel content). For operationalizing quality, we used paper order and lead article variables as indicative of an article's quality.

According to social constructivism, an article's impact is dependent upon the authors who are involved in writing the article (Meyer et al., 2018). According to this perspective, the major driver of citations is the authors' social and intellectual connectivity. We used variables such as number of authors (indicative of social connectivity), number of references (indicative of intellectual connectivity), and author's affiliation (US affiliation and affiliation with top institution).

According to the presentation perspective, an article's impact is determined by the manner in which it is presented (Stremersch et al., 2007; Dontu et al., 2021c). Here, the focus as a citation driver is an article's expositional clarity and its attractiveness to prospective citing authors. Accordingly, we used title length (indicative of articles attractiveness to prospective citing authors), abstract length, and number of keywords (indicative of its expositional clarity) as key variables.

\subsection{Regression Analysis}

Table 10 shows the correlation among the variables in our model. Because the relationships are too numerous, we focused only on the correlation of different independent variables with the dependent variable. We found that age had a positive correlation with total citations, which we expected because the older articles had more time to get cited. However, the relationship may not be linear (Baker et al., 2020), and the results of regression may be able to shed more light on it. Among the "universalist" variables, single-country focus had a negative correlation with citations, but "methods" had a positive correlation. Interviews and surveys had a negative correlation, but archival data had a positive correlation. Furthermore, article length had negative correlation. Among the social constructivist variables, the number of 


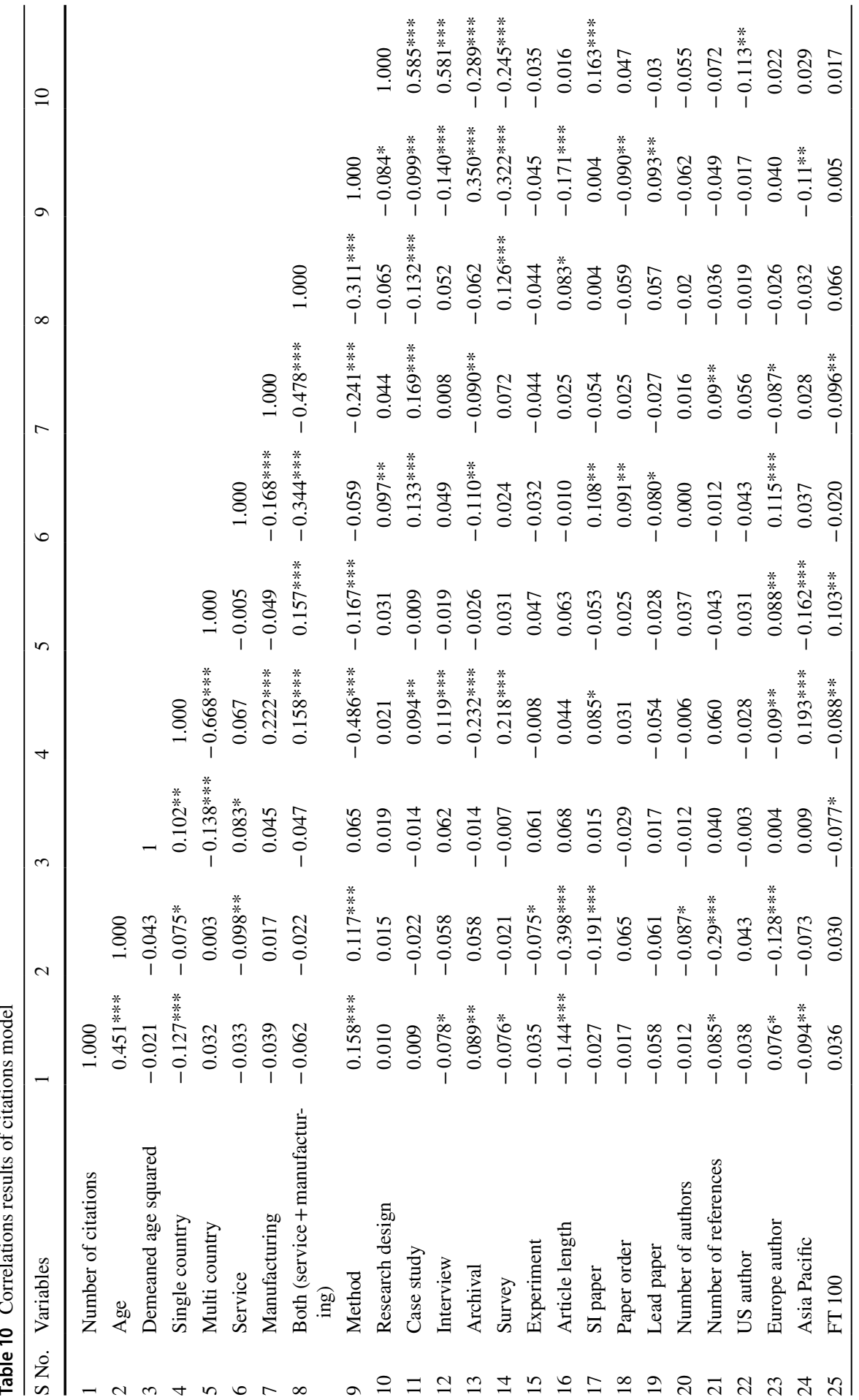




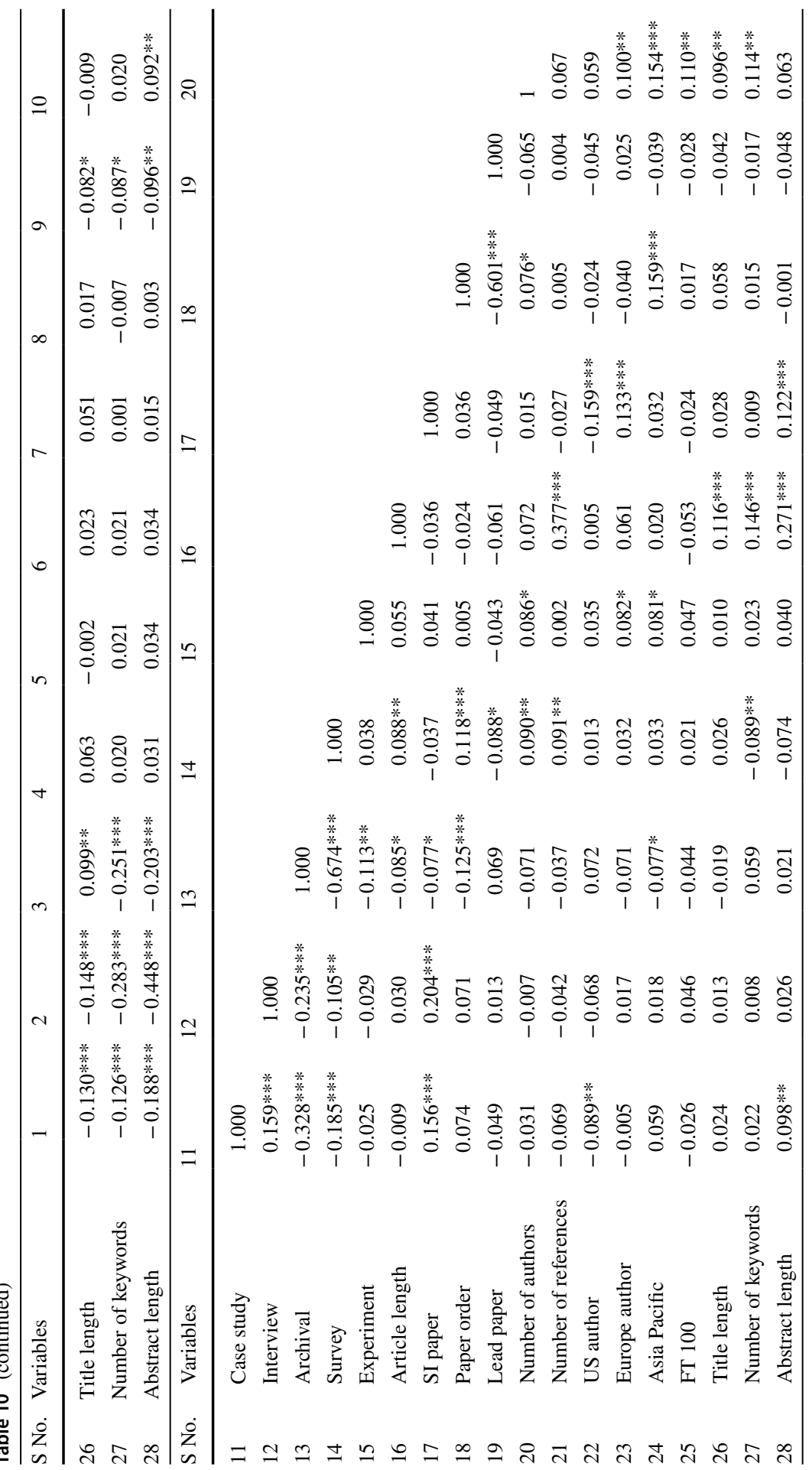




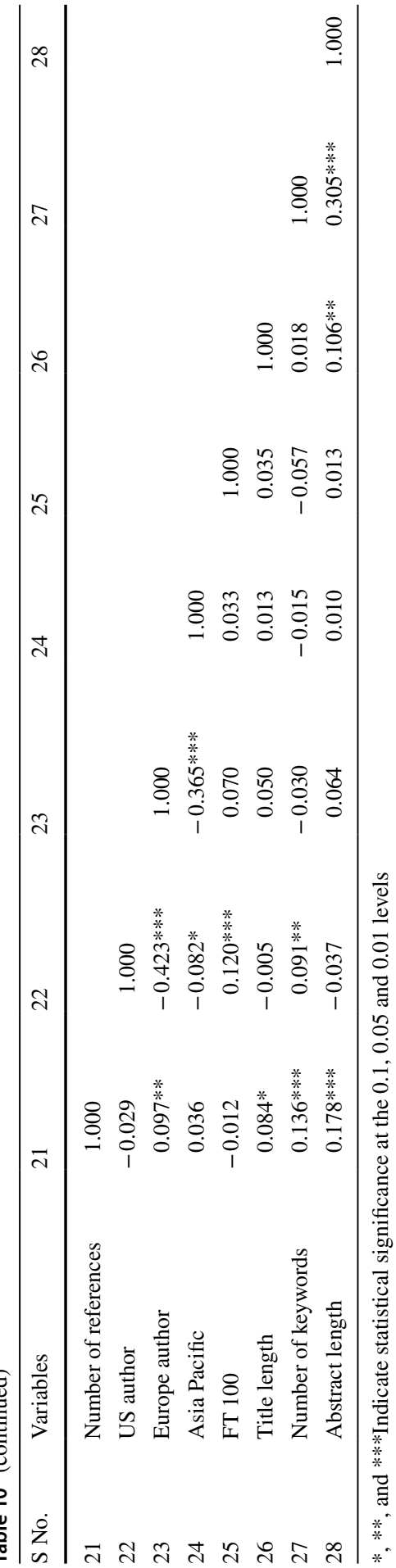


Table 11 Regression results

\begin{tabular}{|c|c|c|c|c|c|}
\hline \multirow[b]{2}{*}{ Parameter } & \multicolumn{2}{|c|}{$\begin{array}{l}\text { Model: Negative binomial } \\
\text { regression dependent } \\
\text { variables: TC }\end{array}$} & \multicolumn{2}{|c|}{$\begin{array}{l}\text { Model: Linear regression } \\
\text { dependent variables: } \mathrm{C} / \mathrm{Y}\end{array}$} & \multirow[t]{2}{*}{ VIF } \\
\hline & $\mathrm{B}$ & Std. error & $\mathrm{B}$ & Std. error & \\
\hline (Intercept) & 1.261 & $(0.532)^{* *}$ & 74.110 & $(14.697)^{* * *}$ & - \\
\hline Age & 0.197 & $(0.014)^{* * *}$ & - & - & 1.681 \\
\hline Demeaned age squared & -0.018 & $(0.003)^{* * *}$ & - & - & 1.067 \\
\hline Single country & 0.096 & $(0.263)$ & 2.767 & $(8.536)$ & 7.661 \\
\hline Multi country & 0.120 & $(0.249)$ & 5.457 & $(8.249)$ & 5.705 \\
\hline Service & -0.088 & $(0.249)$ & -8.845 & $(7.313)$ & 2.199 \\
\hline Manufacturing & -0.189 & $(0.247)$ & -6.430 & $(7.162)$ & 3.343 \\
\hline Both & -0.083 & $(0.22)$ & -6.682 & $(6.271)$ & 4.169 \\
\hline Method & 0.309 & $(0.203)$ & 6.504 & $(7.002)$ & 3.301 \\
\hline Design & 0.303 & $(0.256)$ & 9.370 & $(7.785)$ & 2.778 \\
\hline Case study & 0.155 & $(0.288)$ & 5.044 & $(9.037)$ & 2.296 \\
\hline Interview & -0.250 & $(0.223)$ & -10.232 & $(7.268)$ & 1.877 \\
\hline Archival & 0.222 & $(0.184)$ & 6.299 & $(6.420)$ & 4.182 \\
\hline Survey & 0.099 & $(0.188)$ & 1.417 & $(6.572)$ & 3.914 \\
\hline Experiment & -0.233 & $(0.593)$ & -11.456 & (18.27) & 1.146 \\
\hline Article length & 0.008 & $(0.009)$ & -0.394 & $(0.277)$ & 1.410 \\
\hline SI paper & 0.327 & $(0.163)^{* *}$ & -1.431 & $(5.246)$ & 1.182 \\
\hline Paper order & -0.029 & $(0.035)$ & -1.246 & $(1.155)$ & 1.699 \\
\hline Lead paper & -0.031 & $(0.158)$ & -11.031 & $(5.109)^{* *}$ & 1.674 \\
\hline Number of authors & 0.018 & $(0.049)$ & 1.082 & $(1.532)$ & 1.139 \\
\hline Number of references & 0.002 & $(0.001)$ & -0.005 & $(0.030)$ & 1.257 \\
\hline US author & 0.009 & $(0.123)$ & -2.457 & $(3.993)$ & 1.481 \\
\hline Europe author & 0.311 & $(0.128)^{* *}$ & 4.290 & (4.109) & 1.804 \\
\hline Asia Pacific & -0.023 & $(0.124)$ & -4.130 & $(3.997)$ & 1.530 \\
\hline FT 100 & 0.071 & $(0.11)$ & 2.842 & $(3.629)$ & 1.104 \\
\hline Title length & -0.010 & $(0.012)$ & -0.901 & $(0.408)^{* *}$ & 1.052 \\
\hline Number of keywords & -0.001 & $(0.033)$ & -1.524 & $(1.050)$ & 1.208 \\
\hline Abstract length & -0.001 & $(0.001)$ & -0.119 & $(0.039)^{* * *}$ & 1.384 \\
\hline Akaike's information criterion (AIC) & 4033.299 & & R-Squared & $0.117 * * *$ & \\
\hline Bayesian information criterion (BIC) & 4150.742 & & & & \\
\hline Log likelihood & -1988.65 & & & & \\
\hline
\end{tabular}

$*, * *$, and $* * *$ Indicate statistical significance at the $0.1,0.05$ and 0.01 levels

references and the author's affiliation to Asia-Pacific countries had a negative correlation, but the affiliation to European countries had a positive correlation. Among the presentation variables, title length, number of keywords, and abstract length had a negative correlation.

Table 11 presents the results of the negative binomial regression. The results of negative binomial regression suggest that the methodology-related variables might 
not play a role in driving citations. However, the citations were driven by the publication in a special issue, indicating that articles having focused and timely topics may receive more citations. Furthermore, European authors positively drove citations, indicating that the authors from this region may bring in more citations.

\subsection{Robustness}

We used the second model with "citations per year" to conduct a robustness check on our model. The variance inflation factors (VIF) in the model suggest that it does not suffer from a multicollinearity issue. The r-squared value at 0.117 is comparable to previous research (e.g., Baker et al., 2020; Donthu et al., 2021b). Further, we found the direction of relationships across both models, with the second model showing a significant effect for the lead paper, title length, and abstract length. Their directions remain the same though, indicating that the model is robust.

\section{Comparison of MIR with JIBS, JWB, GSJ, MOR, IBR, JIM, and APJM}

Table 12 shows the comparison of MIR with other leading IB journals. We took the list from the list of top IB journals by Tüselmann et al. (2016), with a threshold of a 3 AJG rating. Eight journals presented in the list have an AJG rating of 3 or greater. Here, only JIBS has a $4 *$ rating, while JWB and GSJ are rated 4 . This presents a list of journals with which MIR may want to compete in the future. JIBS and JWB, in particular, are the journals that it may want to emulate in terms of future performance. Similar to $M I R$, both journals are 50 years or older and, thus, present a viable comparison.

In terms of aims and scope, MIR is similar to JIBS, JWB, and JIM as these journals have a global outreach, while covering topics related to IB and IM that span geographical, cultural, institutional, and organizational boundaries. GSJ, APJM, and $M O R$ are comparatively narrower and more specific in their content. For instance, $G S J$ focuses primarily on the strategic aspects of IB, which is not surprising as it is published by the Strategic Management Society (their other journal being Strategic Management Journal). APJM, while being closer to MIR in terms of their themes, differs in its regional focus. APJM concentrates primarily on the issues related to the Asia-Pacific region (as its name suggests), while $M O R$ focuses primarily on the regional context of China (and sometimes India). We believe that going forward, $J I B S, J W B$, and $J I M$ should provide appropriate points of comparison for MIR.

Table 13 presents the period-wise list of keywords in combined corpus of the $J I B S, J W B, G S J, M O R, I B R, J I M$, and APJM. The temporal list shows that, between 2006 and 2010, the leading journals focused on the topics related to internationalization, culture, institutions, knowledge transfer, offshoring corporate governance, and entrepreneurship. During this time, the dominant clusters in MIR were clusters 1, 2 and 3, dealing with the subject matter related to culture, emerging economies, innovation, knowledge transfer, and absorptive capacity, which lines up well with what the other journals were doing this time. However, there are topics, such as 


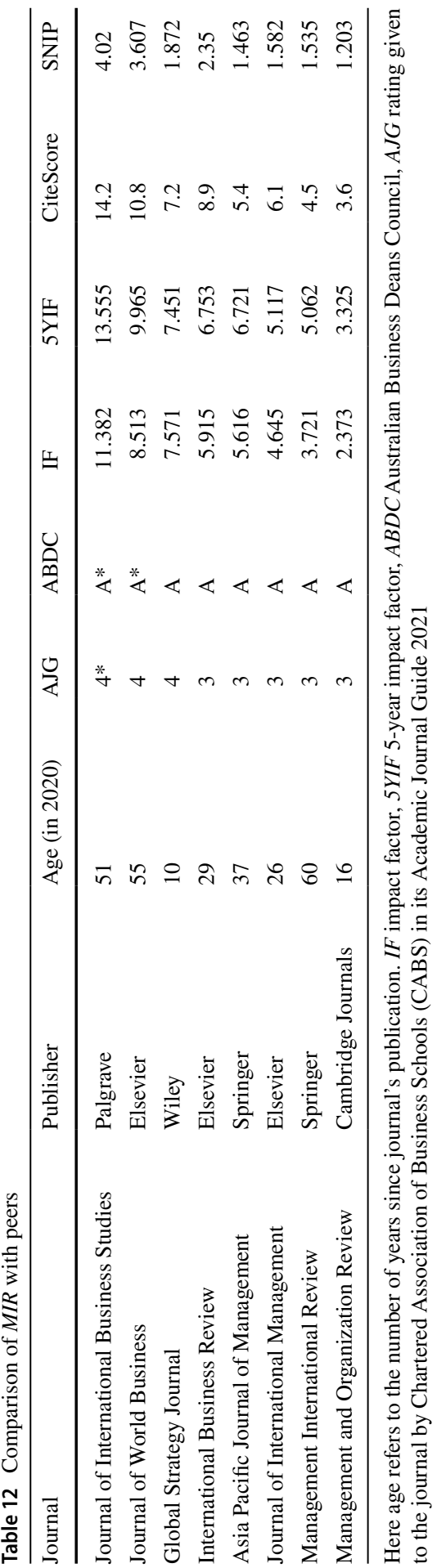




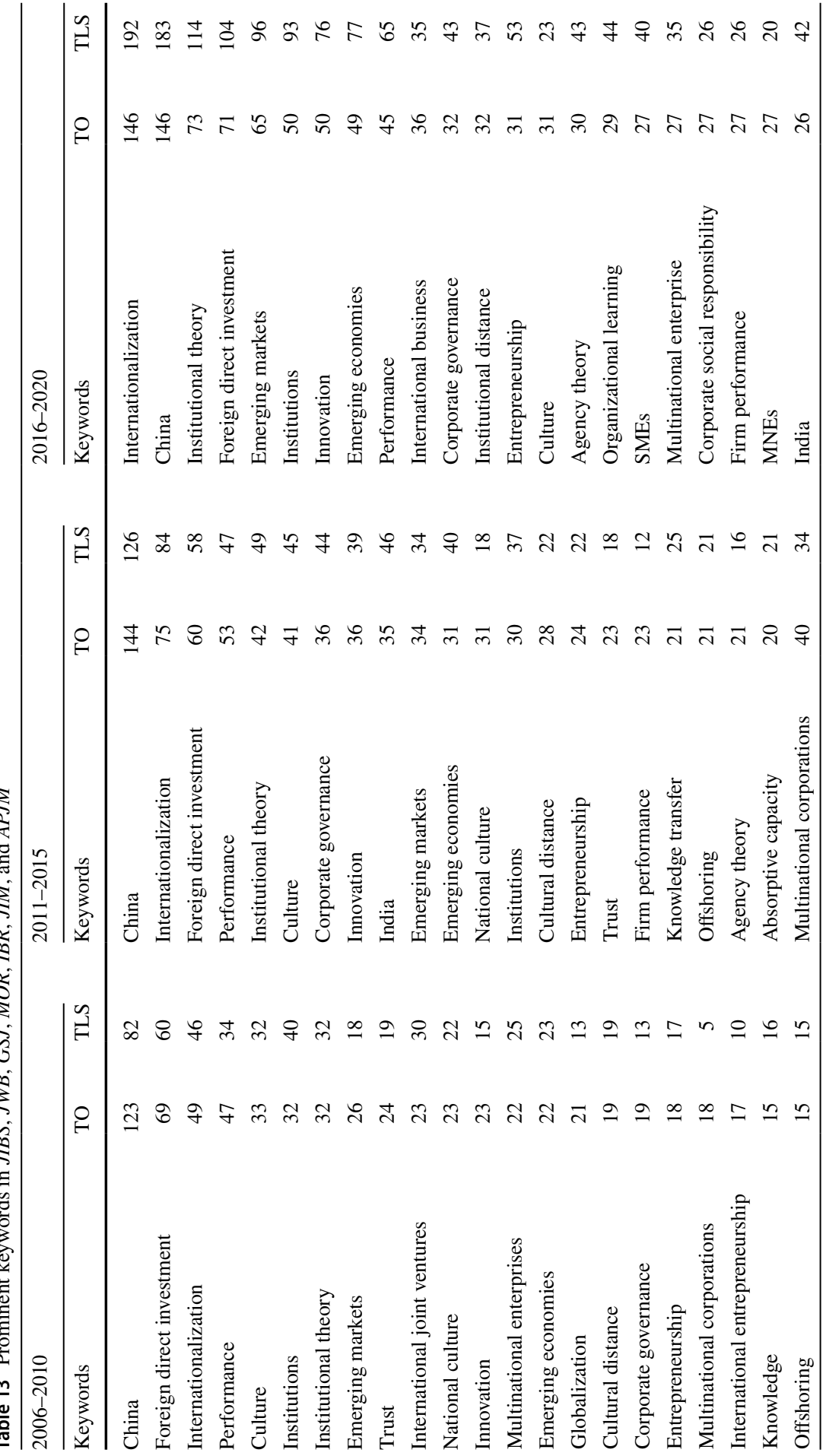




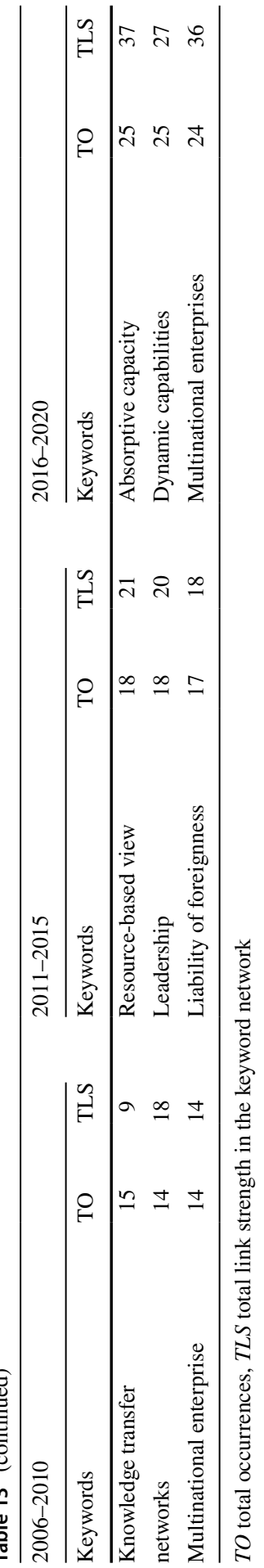


entrepreneurship, where the journal seems to have followed the field. The China institutional context has been popular in the area.

Between 2011 and 2015, the leading journals of IB focused on similar topics as before, with greater focus on IB cultural aspects, as indicated by the rise in the occurrence of keywords, such as culture and cultural distance, and the introduction of new keywords, such as liability of foreignness. The focus of MIR during this time kept up with the field in publishing topics related to international entrepreneurship, a topic that was not prominent in the previous period. The focus on the institutional context of China remained consistent during this period.

In the last 5 years (2016-2020), the topics pursued by the leading journals, while largely remaining similar, have focused more on the institutional aspect of IB, as indicated by keywords such as corporate governance and corporate social responsibility (Bhaumik et al., 2019; Jamali et al., 2020). The focus was on the internationalization in new firms and small firms. While the focus of $M I R$ has largely been the same, the topics related to institutional aspects of IB may not have been given much attention. Similarly, the current COVID-19 pandemic has compelled firms worldwide to rethink their strategies at all levels (Donthu \& Gustafsson, 2020). This is also reflected in the current call for papers or in published research in the leading IB journals. Thus, it will be important for future MIR scholars to re-examine the core IB issues in the backdrop of the pandemic.

\section{Conclusion}

In this study, we used a range of tools, such as coauthorship analysis, bibliographic coupling, and regression analysis, to conduct a comprehensive review of the MIR corpus between 2006 and 2020. We justified the use of these quantitative techniques by the largeness of the journal's corpus (491 articles). Through these analytical techniques, we presented a MIR retrospective, while providing future directions. To provide a better structure, we divided the analysis into five RQs. The summary of findings for each of the questions is as follows.

RQ1 deals with the collaboration patterns among MIR authors. We find that, at times, the journal's authors have chosen to collaborate more, with the author teams' median size increasing consistently. Similarly, the collaboration network at the country level reveals that the network has grown to be more international over time.

RQ2 deals with the methodological choices of MIR authors. In terms of industry focus, we found a shift towards service industries. In terms of geographic focus, Asia seems to be the most popular choice among single-country studies. We found that the authors have chosen to conduct more empirical and quantitative studies. We also found that the archival data sources were the most popular in the journal, with regression and related techniques being the preferred methods of data analysis.

RQ3 deals with the major themes present in the MIR corpus. Using bibliographic coupling, we found that the authors focused on the themes related to "culture", "emerging economies", "innovation, knowledge transfer, absorptive capacity", "internationalization process", "culture and entry modes", and "internationalization 
and performance". We found that, over time, the journal's focus has shifted more toward cross-cultural management issues.

RQ4 deals with the drivers of MIR citation. For this purpose, we used a negative binomial regression model and found that, while methodology and industry and regional focus did not have an impact on citation, the publication in a focused or special issue and affiliation to a European institution did have a positive impact on citations. The journal publishes at least two focused or special issues every year and is based in Europe, which may increase its citations.

Finally, RQ5 deals with MIR's comparison with other leading journals in the field. We found that, while the journal enjoys a great reputation in the scholarly community, it has much room to grow. In this regard, JIBS and JWB can act as obvious benchmarks for the journal to reach in the future. In terms of themes, we found that the journal's themes are largely in line with other leading journals in the field.

In sum, we attempted to present a retrospective of $M I R$ on the occasion of its $60^{\text {th }}$ anniversary. There was a limit on the availability of bibliographic data. As the data present on Scopus covers only approximately 15 years of the journal, we were only able to cover these years in the study. Second, there was a limitation at the source, and the errors at the source of data can affect the outcomes of the study. The comprehensive databases are not built specifically for bibliometric analysis and, therefore, may contain errors that might affect the study. Nevertheless, the contributions easily outweigh the limitations. Our analysis contributes to the scholarship in multiple ways. First, we carried out a performance analysis of the journal, which could help the editorial team to track the journal productivity. A mapping analysis of the journal's performance may help the editorial team to discover ideas for the journal's further intellectual evolution. The study of methodologies and theories used in journal articles may help the editorial board diversify the issues on which they publish contributions. The authorship analysis showed that the journal has expanded toward greater collaboration. Moreover, the contribution lies in analyzing central themes and the journal's development in terms of the research topics covered. As MIR is one of the leading journals in its domain, these results may apply to the entire field, and future researchers may explore the broad research directions we provided.

\section{References}

Acedo, F. J., Barroso, C., Casanueva, C., \& Galan, J. L. (2006). Co-authorship in management and organizational studies: An empirical and network analysis. Journal of Management Studies, 43(5), 957-983.

Akkermans, D., Harzing, A. W., \& van Witteloostuijn, A. (2010). Cultural accommodation and language priming: Competitive versus cooperative behavior in a prisoner's dilemma game. Management International Review, 50(5), 559-583.

Ambos, B., \& Mahnke, V. (2010). How do MNC headquarters add value? Management International Review, 50(4), 403-412.

Ambos, T. C., \& Birkinshaw, J. (2010). Headquarters' attention and its effect on subsidiary performance. Management International Review, 50(4), 449-469.

Ambos, B., Brandl, K., Perri, A., Scalera, V. G., \& Van Assche, A. (2021). The nature of innovation in global value chains. Journal of World Business, 56(4), 101221. 
Arregle, J. L., Hébert, L., \& Beamish, P. W. (2006). Mode of international entry: The advantages of multilevel methods. Management International Review, 46(5), 597-618.

Arregle, J. L., Chirico, F., Kano, L., Kundu, S. K., Majocchi, A., \& Schulze, W. S. (2021). Family firm internationalization: Past research and an agenda for the future. Journal of International Business Studies, 52(6), 1159-1198.

Augier, M., \& Teece, D. J. (2007). Dynamic capabilities and multinational enterprise: Penrosean insights and omissions. Management International Review, 47(2), 175-192.

Bai, T., Chen, S., \& He, X. (2019). How home-country political connections influence the internationalization of service firms. Management International Review, 59(4), 541-560.

Baker, H. K., Kumar, S., \& Pandey, N. (2020). A bibliometric analysis of European financial management's first 25 years. European Financial Management, 26(5), 1224-1260.

Ball, D. A., Lindsay, V. J., \& Rose, E. L. (2008). Rethinking the paradigm of service internationalisation: Less resource-intensive market entry modes for information-intensive soft services. Management International Review, 48(4), 413-431.

Banerjee, S., \& Venaik, S. (2018). The effect of corporate political activity on MNC subsidiary legitimacy: An institutional perspective. Management International Review, 58(5), 813-844.

Bastian, M., Heymann, S., \& Jacomy, M. (2009). Gephi: An open source software for exploring and manipulating networks. In Proceedings of the Third International ICWSM Conference (2009) (pp. 361-362).

Bausch, A., \& Krist, M. (2007). The effect of context-related moderators on the internationalizationperformance relationship: Evidence from meta-analysis. Management International Review, 47(3), 319-347.

Bhardwaj, A., Dietz, J., \& Beamish, P. W. (2007). Host country cultural influences on foreign direct investment. Management International Review, 47(1), 29-50.

Bhaumik, S., Driffield, N., Gaur, A., Mickiewicz, T., \& Vaaler, P. (2019). Corporate governance and MNE strategies in emerging economies. Journal of World Business, 54(4), 234-243.

Blagoeva, D. H., Jensen, P. D. Ø., \& Merchant, H. (2020). Services in international business studies: A replication and extension of Merchant and Gaur (2008). Management International Review, 60(3), $427-457$.

Buckley, P. J. (2011). International integration and coordination in the global factory. Management International Review, 51(2), 269-283.

Buckley, P. J., Cross, A. R., Tan, H., Xin, L., \& Voss, H. (2008). Historic and emergent trends in Chinese outward direct investment. Management International Review, 48(6), 715-748.

Burgers, W., \& Padgett, D. (2009). Understanding environmental risk for IJVs in China. Management International Review, 49(3), 337-357.

Calma, A., \& Suder, G. (2020). Mapping international business and international business policy research: Intellectual structure and research trends. International Business Review, 29(3), 101691.

Casprini, E., Dabic, M., Kotlar, J., \& Pucci, T. (2020). A bibliometric analysis of family firm internationalization research: Current themes, theoretical roots, and ways forward. International Business Review, 29(5), 101715.

Cerrato, D., \& Piva, M. (2015). The effect of global orientation on the performance of international new ventures: Evidence from Italy. Management International Review, 55(6), 857-883.

Chan, K. C., Chang, C. H., \& Lo, Y. L. (2009). A retrospective evaluation of European financial management (1995-2008). European Financial Management, 15(3), 676-691.

Chen, H. L., Chang, C. Y., \& Hsu, W. T. (2017). Does board co-working experience influence directors' decisions toward internationalization? Management International Review, 57(1), 65-92.

Child, J., Rodrigues, S. B., \& Frynas, J. G. (2009). Psychic distance, its impact and coping modes Interpretations of SME decision makers. Management International Review, 49(2), 199-224.

Chung, C. C., Lee, S. H., \& Lee, J. Y. (2013). Dual-option subsidiaries and exit decisions during times of economic crisis. Management International Review, 53(4), 555-577.

Contractor, F. J. (2007). Is international business good for companies? The evolutionary or multi-stage theory of internationalization vs the transaction cost perspective. Management International Review, 47(3), 453-475.

Contractor, F. J., \& Mudambi, S. M. (2008). The influence of human capital investment on the exports of services and goods: An analysis of the top 25 services outsourcing countries. Management International Review, 48(4), 433-445.

Contractor, F., Foss, N. J., Kundu, S., \& Lahiri, S. (2019). Viewing global strategy through a microfoundations lens. Global Strategy Journal, 9(1), 3-18. 
Criscuolo, P., \& Narula, R. (2007). Using multi-hub structures for international R\&D: Organisational inertia and the challenges of implementation. Management International Review, 47(5), 639-660.

D’Agostino, L. M., \& Santangelo, G. D. (2012). Do overseas R\&D laboratories in emerging markets contribute to home knowledge creation? An extension of the double diamond model. Management International Review, 52(2), 251-273.

Dang, C., \& Li, Z. F. (2020). Drivers of research impact: Evidence from the top three finance journals. Accounting \& Finance, 60(3), 2759-2809.

Daniel, S. J., Cieslewicz, J. K., \& Pourjalali, H. (2012). The impact of national economic culture and country-level institutional environment on corporate governance practices. Management International Review, 52(3), 365-394.

Del Bosco, B., \& Bettinelli, C. (2020). How do family SMEs control their investments abroad? The role of distance and family control. Management International Review, 60(1), 1-35.

Demirbag, M., Tatoglu, E., \& Glaister, K. W. (2008). Factors affecting perceptions of the choice between acquisition and greenfield entry: The case of Western FDI in an emerging market. Management International Review, 48(1), 5-38.

Dhanaraj, C., \& Beamish, P. W. (2009). Institutional environment and subsidiary survival. Management International Review, 49(3), 291-312.

Donthu, N., \& Gustafsson, A. (2020). Effects of COVID-19 on business and research. Journal of Business Research, 117, 284-289.

Donthu, N., Kumar, S., Mukherjee, D., Pandey, N., \& Lim, W. M. (2021a). How to conduct a bibliometric analysis: An overview and guidelines. Journal of Business Research, 133, 285-296.

Donthu, N., Kumar, S., Pandey, N., \& Gupta, P. (2021b). Forty years of the International Journal of Information Management : A bibliometric analysis. International Journal of Information Management. https://doi.org/10.1016/j.ijinfomgt.2020.102307

Donthu, N., Kumar, S., Pandey, N., \& Lim, W. M. (2021c). Research constituents, intellectual structure, and collaboration patterns in Journal of International Marketing: An analytical retrospective. Journal of International Marketing, 29(2), 1-25.

Donthu, N., Kumar, S., \& Pattnaik, D. (2020). Forty-five years of journal of business research: A bibliometric analysis. Journal of Business Research, 109, 1-14.

Donthu, N., Kumar, S., Pattnaik, D., \& Pandey, N. (2021d). A bibliometric review of International Marketing Review (IMR): Past, present, and future. International Marketing Review. https://doi.org/10. 1108/IMR-11-2020-0244 ahead-of-p(ahead-of-print).

Dorfman, P., Javidan, M., Hanges, P., Dastmalchian, A., \& House, R. (2012). GLOBE: A twenty year journey into the intriguing world of culture and leadership. Journal of World Business, 47(4), $504-518$.

Dow, D., \& Larimo, J. (2011). Disentangling the roles of international experience and distance in establishment mode choice. Management International Review, 51(3), 321-355.

Elango, B., \& Pattnaik, C. (2011). Learning before making the big leap: Acquisition strategies of emerging market firms. Management International Review, 51(4), 461-481.

Elango, B., \& Sethi, S. P. (2007). An exploration of the relationship between country of origin (COE) and the internationalization-performance paradigm. Management International Review, 47(3), 369-392.

Ferreras-Méndez, J. L., Fernández-Mesa, A., \& Alegre, J. (2019). Export performance in SMEs: The importance of external knowledge search strategies and absorptive capacity. Management International Review, 59(3), 413-437.

Fortanier, F., Kolk, A., \& Pinkse, J. (2011). Harmonization in CSR reporting: MNEs and global CSR standards. Management International Review, 51(5), 665-696.

Fu, P. P., Tsui, A. S., \& Dess, G. G. (2006). The dynamics of Guanxi in Chinese high-tech firms: Implications for knowledge management and decision making. Management International Review, 46(3), $277-305$.

Galkina, T., \& Chetty, S. (2015). Effectuation and networking of internationalizing SMEs. Management International Review, 55(5), 647-676.

García-Lillo, F., Claver-Cortés, E., Marco-Lajara, B., \& Úbeda-García, M. (2019). Identifying the 'knowledge base' or 'intellectual structure' of research on international business, 2000-2015: A citation/co-citation analysis of JIBS. International Business Review, 28(4), 713-726.

Gaur, A., \& Delios, A. (2015). International diversification of emerging market firms: The role of ownership structure and group affiliation. Management International Review, 55(2), 235-253. 
Glaister, K. W., Driffield, N., \& Lin, Y. (2020). Foreign direct investment to Africa: Is there a colonial legacy? Management International Review, 60(3), 315-349.

Gong, Y. (2006). The impact of subsidiary top management team national diversity on subsidiary performance: Knowledge and legitimacy perspectives. Management International Review, 46(6), 771-790.

Guffey, D. M., \& Harp, N. L. (2014). Ranking faculties, PhD programs, individual scholars, and influential articles in accounting information systems based on citations to publications in the Journal of Information Systems. Journal of Information Systems, 28(1), 111-144.

Gupta, S., Verma, R., \& Victorino, L. (2006). Empirical research published in production and operations management (1992-2005): Trends and future research directions. Production and Operations Management, 15(3), 432-448.

Hagen, B., \& Zucchella, A. (2014). Born global or born to run? The long-term growth of born global firms. Management International Review, 54(4), 497-525.

Han, X., Liu, X., Gao, L., \& Ghauri, P. (2018). Chinese multinational enterprises in Europe and Africa: How do they perceive political risk? Management International Review, 58(1), 121-146.

Hanson, D., \& Grimmer, M. (2007). The mix of qualitative and quantitative research in major marketing journals, 1993-2002. European Journal of Marketing, 41(1-2), 58-70.

Harzing, A. W., \& Pudelko, M. (2016). Do we need to distance ourselves from the distance concept? Why home and host country context might matter more than (cultural) distance. Management International Review, 56(1), 1-34.

Hennart, J. F. (2007). The theoretical rationale for a multinationality-performance relationship. Management International Review, 47(3), 423-452.

Hilmersson, M., \& Johanson, M. (2016). Speed of SME internationalization and performance. Management International Review, 56(1), 67-94.

Hota, P. K., Subramanian, B., \& Narayanamurthy, G. (2019). Mapping the intellectual structure of social entrepreneurship research: A citation/co-citation analysis. Journal of Business Ethics, 166(1), 89-114.

House, R. J., Hanges, P. J., Javidan, M., Dorfman, P. W., \& Gupta, V. (Eds.). (2004). Culture, leadership, and organizations: The GLOBE study of 62 societies. Sage publications.

Hurmerinta-Peltomäki, L., \& Nummela, N. (2006). Mixed methods in international business research: A value-added perspective. Management International Review, 46(4), 439-459.

Hutchings, K., Michailova, S., \& Harrison, E. C. (2013). Neither ghettoed nor cosmopolitan: A study of Western women's perceptions of gender and cultural stereotyping in the UAE. Management International Review, 53(2), 291-318.

Jain, N. K., Kothari, T., \& Kumar, V. (2016). Location choice research: Proposing new agenda. Management International Review, 56(3), 303-324.

Jamali, D., Jain, T., Samara, G., \& Zoghbi, E. (2020). How institutions affect CSR practices in the Middle East and North Africa: A critical review. Journal of World Business, 55(5), 101127.

Jha, S. K., Dhanaraj, C., \& Krishnan, R. T. (2018). From arbitrage to global innovation: Evolution of multinational R\&D in emerging markets. Management International Review, 58(4), 633-661.

Jiménez, A., Russo, M., Kraak, J. M., \& Jiang, G. F. (2017). Corruption and private participation projects in Central and Eastern Europe. Management International Review, 57(5), 775-792.

Jintae, F., Kwanghyun, F., \& Eng, A. (2016). Language, cultural intelligence, and inpatriate turnover intentions: Leveraging values in multinational corporations through inpatriates. Management International Review., 56(2), 283-301.

Johanson, J., \& Vahlne, J. E. (2006). Commitment and opportunity development in the internationalization process: A note on the Uppsala internationalization process model. Management International Review, 46(2), 165-178.

Jormanainen, I., \& Koveshnikov, A. (2012). International activities of emerging market firms: A critical assessment of research in top international management journals. Management International Review, 52(5), 691-725.

Kaufmann, L., \& Körte, P. (2010). Responses of advanced country MNEs to low-cost country imports in their home markets. Management International Review, 50(2), 241-262.

Kedia, B., Gaffney, N., \& Clampit, J. (2012). EMNEs and knowledge-seeking FDI. Management International Review, 52(2), 155-173.

Kessler, M. M. (1963). Bibliographic coupling between scientific articles. American Documentation, 14(1), 123-131. 
Kim, D., \& Cavusgil, E. (2020). Antecedents and outcomes of digital platform risk for international new ventures' internationalization. Journal of World Business, 55(1), 101021.

Kim, H. G., Gaur, A. S., \& Mukherjee, D. (2020). Added cultural distance and ownership in cross-border acquisitions. Cross Cultural and Strategic Management, 27(3), 487-510.

Kotabe, M., Mol, M. J., \& Ketkar, S. (2008). An evolutionary stage model of outsourcing and competence destruction: A triad comparison of the consumer electronics industry. Management International Review, 48(1), 65-94.

Kumar, V., Borah, S. B., Sharma, A., \& Akella, L. Y. (2021). Chief marketing officers' discretion and firms' internationalization: An empirical investigation. Journal of International Business Studies, 52(3), 363-387.

Kumar, V., Singh, D., Purkayastha, A., Popli, M., \& Gaur, A. (2020). Springboard internationalization by emerging market firms: Speed of first cross-border acquisition. Journal of International Business Studies, 51(2), 172-193.

Kwon, K., Bae, J., \& Lawler, J. J. (2010). High commitment HR practices and top performers: Impacts on organizational commitment. Management International Review, 50(1), 57-80.

Lahiri, S., Mukherjee, D., \& Peng, M. W. (2020). Behind the internationalization of family SMEs: A strategy tripod synthesis. Global Strategy Journal, 10(4), 813-838.

Lee, J. Y., Jiménez, A., \& Devinney, T. M. (2020a). Learning in SME Internationalization: A new perspective on learning from success versus failure. Management International Review, 60(4), 485-513.

Lee, J. Y., Taras, V., Jiménez, A., Choi, B., \& Pattnaik, C. (2020b). Ambidextrous knowledge sharing within R\&D teams and multinational enterprise performance: The moderating effects of cultural distance in uncertainty avoidance. Management International Review, 60(3), 387-425.

Li, S., Fetscherin, M., Alon, I., Lattemann, C., \& Yeh, K. (2010). Corporate social responsibility in emerging markets: The importance of the governance environment. Management International Review, 50(5), 635-654.

Liedong, T. A., \& Frynas, J. G. (2018). Investment climate constraints as determinants of political tie intensity in emerging countries: Evidence from foreign firms in Ghana. Management International Review, 58(5), 675-703.

Liesch, P. W., Welch, L. S., \& Buckley, P. J. (2011). Risk and uncertainty in internationalisation and international entrepreneurship studies: Review and conceptual development. Management International Review, 51(6), 851-873.

Lin, N. (2020). Designing global sourcing strategy for cost savings and innovation: A configurational approach. Management International Review, 60(5), 723-753.

Lind, C. H., \& Kang, O. H. (2017). The value-adding role of the corporate headquarters in innovation transfer processes: The issue of headquarters knowledge situation. Management International Review, 57(4), 571-602.

Lindeque, J., \& McGuire, S. (2007). The United States and trade disputes in the World Trade Organization: Hegemony constrained or confirmed? Management International Review, 47(5), 725-744.

Majocchi, A., \& Strange, R. (2012). International diversification: The impact of ownership structure, the market for corporate control and board independence. Management International Review, 52(6), 879-900.

Makarius, E. E., Mukherjee, D., Fox, J. D., \& Fox, A. K. (2020). Rising with the machines: A sociotechnical framework for bringing artificial intelligence into the organization. Journal of Business Research, 120, 262-273.

Manning, S., Lewin, A., \& Schuerch, M. (2011). The stability of offshore outsourcing relationships. Management International Review, 51(3), 381-406.

Mariotti, S., Marzano, R., \& Piscitello, L. (2021). The role of family firms' generational heterogeneity in the entry mode choice in foreign markets. Journal of Business Research, 132, 800-812.

Merchant, H., \& Gaur, A. (2008). Opening the 'non-manufacturing'envelope: The next big enterprise for international business research. Management International Review, 48(4), 379-396.

Meyer, M., Waldkirch, R. W., Duscher, I., \& Just, A. (2018). Drivers of citations: An analysis of publications in “top" accounting journals. Critical Perspectives on Accounting, 51(1), 24-46.

Minbaeva, D. B. (2007). Knowledge transfer in multinational corporations. Management International Review, 47(4), 567-593.

Mingers, J., \& Yang, L. (2017). Evaluating journal quality: A review of journal citation indicators and ranking in business and management. European Journal of Operational Research, 257(1), 323-337. 
Mohr, A., \& Batsakis, G. (2017). Internationalization speed and firm performance: A study of the marketseeking expansion of retail MNEs. Management International Review, 57(2), 153-177.

Mondal, A., Lahiri, S., \& Ray, S. (2021). Strategic response to inward foreign direct investment: A study of Indian family firms. Management International Review, 61(2), 207-233.

Moschieri, C., Ragozzino, R., \& Campa, J. M. (2014). Does regional integration change the effects of country-level institutional barriers on M\&A? The case of the European Union. Management International Review, 54(6), 853-877.

Mu, S., Gnyawali, D. R., \& Hatfield, D. E. (2007). Foreign subsidiaries' learning from local environments: An empirical test. Management International Review, 47(1), 79-102.

Mudambi, R., Mudambi, S. M., Mukherjee, D., \& Scalera, V. G. (2017). Global connectivity and the evolution of industrial clusters: From tires to polymers in Northeast Ohio. Industrial Marketing Management, 61, 20-29.

Mukherjee, D., Makarius, E. E., \& Stevens, C. E. (2021). A reputation transfer perspective on the internationalization of emerging market firms. Journal of Business Research, 123, 568-579.

Nair, S. R., Demirbag, M., \& Mellahi, K. (2015). Reverse knowledge transfer from overseas acquisitions: A survey of Indian MNEs. Management International Review, 55(2), 277-301.

Najafi-Tavani, Z., Giroud, A., \& Sinkovics, R. R. (2012). Mediating effects in reverse knowledge transfer processes: The case of knowledge-intensive services in the UK. Management International Review, 52(3), 461-488.

Nemeth, A., \& Nippa, M. (2013). Rigor and relevance of IJV exit research. Management International Review, 53(3), 449-475.

Newman, M. E. J., \& Girvan, M. (2004). Finding and evaluating community structure in networks. Physical Review E, 69(2), 26113.

Nummela, N., Saarenketo, S., Jokela, P., \& Loane, S. (2014). Strategic decision-making of a born global: A comparative study from three small open economies. Management International Review, 54(4), 527-550.

Nuruzzaman, N., Singh, D., \& Gaur, A. S. (2020). Institutional support, hazards, and internationalization of emerging market firms. Global Strategy Journal, 10(2), 361-385.

Oesterle, M. J., \& Wolf, J. (2011). 50 Years of management international review and IB/IM research: An inventory and some suggestions for the field's development. Management International Review, 51(6), 735-754.

Pattnaik, C., Singh, D., \& Gaur, A.S. (2020). Home country learning and international expansion of emerging market multinationals. Journal of International Management, 100781.

Peng, M. W., Wang, D. Y., \& Jiang, Y. (2008). An institution-based view of international business strategy: A focus on emerging economies. Journal of International Business Studies, 39(5), 920-936.

Pérez-Nordtvedt, L., Mukherjee, D., \& Kedia, B. L. (2015). Cross-border learning, technological turbulence and firm performance. Management International Review, 55(1), 23-51.

Rabbiosi, L., Elia, S., \& Bertoni, F. (2012). Acquisitions by EMNCs in developed markets: An organisational learning perspective. Management International Review, 52(2), 193-212.

Ragozzino, R. (2009). The effects of geographic distance on the foreign acquisition activity of US firms. Management International Review, 49(4), 509-535.

Ramos-Rodrígue, A. R., \& Ruíz-Navarro, J. (2004). Changes in the intellectual structure of strategic management research: A bibliometric study of the Strategic Management Journal, 1980-2000. Strategic Management Journal, 25(10), 981-1004.

Rialp, A., Merigó, J. M., Cancino, C. A., \& Urbano, D. (2019). Twenty-five years (1992-2016) of the International Business Review: A bibliometric overview. International Business Review, 28(6), 101587.

Rosenzweig, S., Grinstein, A., \& Ofek, E. (2016). Social network utilization and the impact of academic research in marketing. International Journal of Research in Marketing, 33(4), 818-839.

Rugman, A. M., \& Verbeke, A. (2008). A new perspective on the regional and global strategies of multinational services firms. Management International Review, 48(4), 397-411.

Rugman, A. M., Verbeke, A., \& Nguyen, Q. T. K. (2011). Fifty years of international business theory and beyond. Management International Review, 51(6), 755-786.

Ruigrok, W., Amann, W., \& Wagner, H. (2007). The internationalization-performance relationship at Swiss firms: A test of the S-shape and extreme degrees of internationalization. Management International Review, 47(3), 349-368. 
Scalera, V. G., Mukherjee, D., \& Piscitello, L. (2020). Ownership strategies in knowledge-intensive cross-border acquisitions: Comparing Chinese and Indian MNEs. Asia Pacific Journal of Management, 37(1), 155-185.

Schwert, G. W. (1993). The journal of financial economics. A retrospective evaluation (1974-1991). Journal of Financial Economics, 33(3), 369-424.

Singh, D. A., Gaur, A. S., \& Schmid, F. P. (2010). Corporate diversification, TMT experience, and performance: Evidence from German SMEs. Management International Review, 50(1), 35-56.

Sinkovics, N., Choksy, U. S., Sinkovics, R. R., \& Mudambi, R. (2019). Knowledge connectivity in an adverse context: Global value chains and Pakistani offshore service providers. Management International Review, 59(1), 131-170.

Sinkovics, R. R., \& Alfoldi, E. A. (2012). Progressive focusing and trustworthiness in qualitative research: The enabling role of computer-assisted qualitative data analysis software (CAQDAS). Management International Review, 52(6), 817-845.

Sinkovics, R. R., Jean, R. J. B., Roath, A. S., \& Cavusgil, S. T. (2011). Does IT integration really enhance supplier responsiveness in global supply chains? Management International Review, 51(2), 193-212.

Sinkovics, R. R., Penz, E., \& Ghauri, P. N. (2008). Enhancing the trustworthiness of qualitative research in international business. Management International Review, 48(6), 689-714.

Søderberg, A.-M. (2006). Narrative interviewing and narrative analysis in a study of a cross-border merger. Management International Review, 46(4), 397-416.

Song, S. (2014). Subsidiary divestment: The role of multinational flexibility. Management International Review, 54(1), 47-70.

Soontornthum, T., Cui, L., Lu, V. N., \& Su, J. (2020). Enabling SMEs' learning from global value chains: Linking the logic of power and the logic of embeddedness of interfirm relations. Management International Review, 60(4), 543-571.

Stremersch, S., Verniers, I., \& Verhoef, P. C. (2007). The quest for citations: Drivers of article impact. Journal of Marketing, 71(3), 171-193.

Taras, V., Steel, P., \& Kirkman, B. L. (2016). Does country equate with culture? Beyond geography in the search for cultural boundaries. Management International Review, 56(4), 455-487.

Tihanyi, L., Hoskisson, R. E., Johnson, R. A., \& Wan, W. P. (2009). Technological competence and international diversification; The role of managerial incentives. Management International Review, 49(4), 409-431.

Tracey, P., \& Phillips, N. (2011). Entrepreneurship in emerging markets strategies for new venture creation in uncertain institutional contexts. Management International Review, 51(1), 23-39.

Triandis, H. C. (1994). Culture and social behavior. McGraw Hill.

Trompenaars, F. (1993). Riding the Waves of Culture. Nicholas Brealey.

Tsao, S. M., \& Lien, W. H. (2013). Family management and internationalization: The impact on firm performance and innovation. Management International Review, 53(2), 189-213.

Tüselmann, H., Sinkovics, R. R., \& Pishchulov, G. (2016). Revisiting the standing of international business journals in the competitive landscape. Journal of World Business, 51(4), 487-498.

Vahlne, J. E., \& Johanson, J. (2020). The Uppsala model: Networks and micro-foundations. Journal of International Business Studies, 51(1), 4-10.

Valtakoski, A. (2019). The evolution and impact of qualitative research in Journal of Services Marketing. Journal of Services Marketing, 34(1), 8-23.

van Eck, N. J., \& Waltman, L. (2010). Software survey: VOSviewer, a computer program for bibliometric mapping. Scientometrics, 84(2), 523-538.

Verbeke, A., Bachor, V., \& Nguyen, B. (2013). Procedural justice, not absorptive capacity, matters in multinational enterprise ICT transfers. Management International Review, 53(4), 535-554.

Vora, D., Kostova, T., \& Roth, K. (2007). Roles of subsidiary managers in multinational corporations: The effect of dual organizational identification. Management International Review, 47(4), 595-620.

Wallin, J. A. (2005). Bibliometric methods: Pitfalls and possibilities. Basic and Clinical Pharmacology and Toxicology, 97(5), 261-275.

Wang, H., \& Schaan, J. L. (2008). How much distance do we need? Revisiting the "national cultural distance paradox." Management International Review, 48(3), 263-278.

Wei, Z., \& Nguyen, Q. T. K. (2020). Chinese service multinationals: The degree of internationalization and performance. Management International Review, 60(6), 869-908.

Wei, Q., Luo, J. H., \& Huang, X. (2020). Influence of social identity on family firms' FDI decisions: The moderating role of internal capital markets. Management International Review, 60(5), 651-693. 
Welch, C., \& Piekkari, R. (2006). Crossing language boundaries in qualitative interviewing. Management International Review, 46(4), 417-437.

Welch, D. E., \& Welch, L. S. (2008). The importance of language in international knowledge transfer. Management International Review, 48(3), 339-360.

Wright, R. W., \& Ricks, D. A. (1994). Trends in international business research: Twenty-five years later. Journal of International Business Studies, 25(4), 687-701.

Xu, K., Hitt, M. A., \& Dai, L. (2020). International diversification of family-dominant firms: Integrating socioemotional wealth and behavioral theory of the firm. Journal of World Business, 55(3), 101071.

Yang, D., \& Fryxell, G. E. (2009). Brand positioning and anti-counterfeiting effectiveness: A study of managers' perceptions of foreign brands in China. Management International Review, 49(6), 759-779.

Zeng, J., Glaister, K. W., \& Darwish, T. (2019). Processes underlying MNE subsidiary absorptive capacity: Evidence from emerging markets. Management International Review, 59(6), 949-979.

Zeugner-Roth, K. P., Diamantopoulos, A., \& Montesinos, M. Á. (2008). Home country image, country brand equity and consumers product preferences: An empirical study. Management International Review, 48(5), 577-602.

Zhao, H., \& Hsu, C. C. (2007). Social ties and foreign market entry: An empirical inquiry. Management International Review, 47(6), 815-844.

Zhao, H., Zhang, F., \& Kwon, J. (2018). Corporate social responsibility research in international business journals: An author co-citation analysis. International Business Review, 27(2), 389-400.

Publisher's Note Springer Nature remains neutral with regard to jurisdictional claims in published maps and institutional affiliations.

\section{Authors and Affiliations}

\section{Debmalya Mukherjee ${ }^{1} \cdot$ Satish Kumar ${ }^{2,3}$ - Naveen Donthu ${ }^{4} \cdot$ Nitesh Pandey $^{2}$}

Satish Kumar

skumar.dms@mnit.ac.in

Naveen Donthu

ndonthu@gsu.edu

Nitesh Pandey

2018RBM9016@mnit.ac.in

1 Department of Management, College of Business, The University of Akron, 259 South Broadway St, Akron, OH 44325, USA

2 Department of Management Studies, Malaviya National Institute of Technology Jaipur, Jaipur 302017, Rajasthan, India

3 School of Business, Swinburne University of Technology, Jalan Simpang Tiga, 93350 Kuching, Sarawak, Malaysia

4 Department of Marketing, Georgia State University, Atlanta, GA 30303, USA 